\title{
Report on the Impact of Artificial Intelligence on Project Management ${ }^{1}$
}

\author{
AUTHORS (Alphabetical Order): - $\quad$ Adel BELHARET \\ - Urmila BHARATHAN \\ - Benjamin DZINGINA \\ - Neha MADHAVAN \\ - Charul MATHUR ${ }^{2}$ \\ - Yves-Daniel B. TOTI
}

COURSE NAME:

Project 2

PROGRAM:

Management of Technology - Information Systems

SCHOOL:

ESIEE Paris

TUTOR:

Prof. Krzysztof MARKOWSKI

SPONSOR:

Divij BABBAR

DATE OF SUBMISSION:

$30-06-2020$

\footnotetext{
${ }^{1}$ We publish this as a white paper, and the reader is free to cite this for his/her ends. We request the readers to cite this properly while adhering to the international academic standards.

${ }^{2}$ The corresponding author, being the manager who organized this report, is charul.mathur04@gmail.com
} 


\section{PREFACE}

\section{A WORD FROM THE AUTHORS}

The question we attempt to answer can be formulated as «How will AI affect the practice and profession of project management between 2020 and 2030? » Our sponsor intends this report's audience to be "the global community of Management Consultants who know the $P M B o K, B A B o K$, and the standard two year MBA curriculum almost by heart".

It has proved to be quite a challenge for the students (still very junior consultants) to write for such an audience. We hope that the freshness and ingenuousness of our gaze on the problematic will compensate for our lack of experience. As we research and discover sources of information, write, and receive feedback from our stakeholders on our work, our understanding of AI and PM is growing. We had estimated a total of 388 man-hours for the production of this report. We have tracked that the actuals were a total of 627 hours.

Doing all this in virtual mode during COVID-19 lockdown is not easy but we have done our best.

\section{A WORD FROM THE SPONSOR}

I often claim that people not well suited to management are; the incurious, the humorless, the inarticulate, the introverted, and the intransigent. To their certainty of self, they ally boredom. On the other hand, one can be an excellent manager with rather simple skills which involve people, writing, presentation, some arithmetic, and rudimentary reasoning from first principles. During the last couple of years, through my continual interaction with the executive management of my clients (people having none of the former traits, and almost full of the latter traits), I've sensed that workplace humour has steadily been reducing to jokes about how AI will make all of us obsolete in my lifetime. How the mighty have fallen! (Dys/U)topian visions of self-running companies, with minimal requirement of face-to-face interaction, \& self-running lines of business seem to be the punchline. So since the time when I first took notice of such offhand remarks, to today when I think I have much more responsibility than can be justified, I have been thinking about AI and how it will impact my profession.

In order to solve these problems first on paper, and then attempting to live the solution in reality, I imagined a roadmap (based on a decision tree) to understand the various possible outcomes on the different "paths" . Always having lost time in thought myself, I've learnt that thought experiments do have value. I decided to get some help in refining my thoughts on these issues by involving these 6 bright students, and I gave them a small part of the overall question I am pondering in the form of this small project. An obligatory passage point, regarding how Management will be affected by AI.

I appeal to everyone involved at the intersection of Management \& Technology to read this report. If a group of students can study a problem and then answer it with this degree of professionalism in just a couple of weeks, then I see no reason why we should not judge ourselves against the same high standards. We should be adapting rapidly to this oncoming change and using our (considerable?) resources to lead the industry and participate in setting up the dominant design of managing this field. Thus far, I do not align with the notion that this game between AI and Management is zero-sum. 


\section{ACKNOWLEDGEMENT}

The team recognizes that this Project resides in the overall MSc MoTIS structure; so we would like to thank the course administration (especially Doudou Sidibe) for making this possible during this particularly difficult pandemic strained year.

We would like to profusely thank our tutor, Professor Krzysztof Markowski, whose help, stimulating suggestions and encouragement, helped us to coordinate and complete this project. He was always available whenever we needed help. His comments and suggestions were truly positive and gave us positive feedback and helped us in the successful completion of this project.

The team wants to thank each of its members as well, because we always supported \& encouraged each other during the journey of this project. The completion of this project could not have been accomplished without such wonderful and dedicated team members who kept each other focussed and target bound and marched on even though sometimes it was difficult to see over the next hill.

Finally, we want to acknowledge our indebtedness and a deep sense of gratitude towards Divij Babbar, who sponsored this project and whose valuable guidance and supervision were provided throughout the project.

This project is dedicated to everyone who helped us during this project, and during our entire course of studies. 


\section{TABLE OF CONTENTS}

1. Executive Summary ............................................6

2. AI \& Project Management Overview

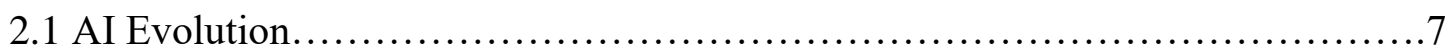

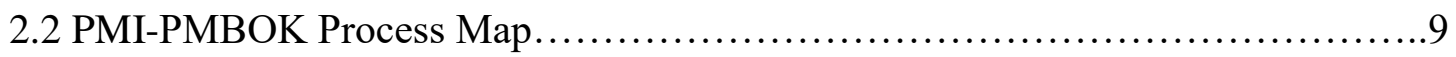

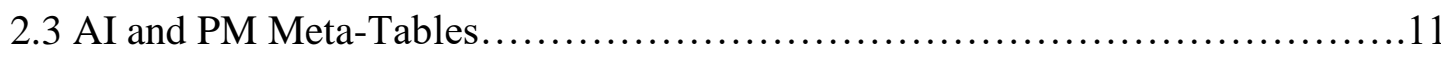

3. AI and Project Management

3.1 Industries more amenable to implementing AI.................................14

3.2 Impact of AI on Project Management day-to-day in these industries...............15

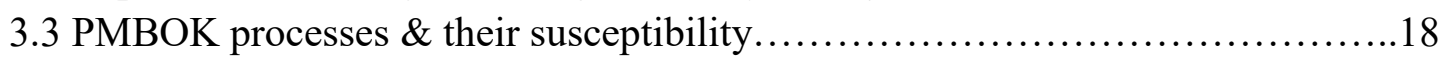

3.4 Existing AI \& Project Management methodologies................................21

3.5 Risks \& limitations of AI in Project Management................................26

\section{AI and Project Manager}

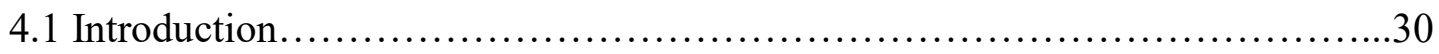

4.2 Impact of AI on Project Manager.................................................. 30

4.3 AI Tools and Techniques for the Project Manager role............................32

4.3.1 A future review on Project Managers...................................33

4.3.2 Building on Project Management Skills................................34

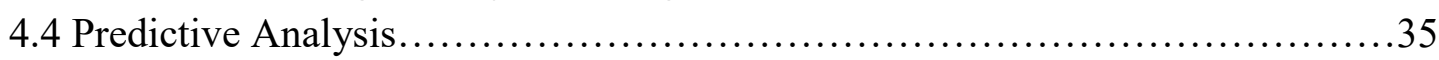

4.4.1 How does Predictive Analytics help Project Managers?.........................36

\section{Future of Project Management Office}

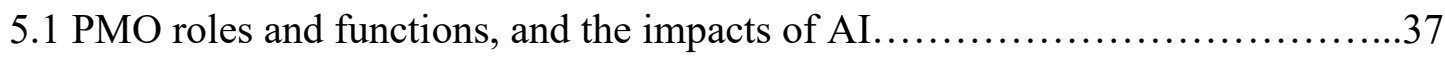

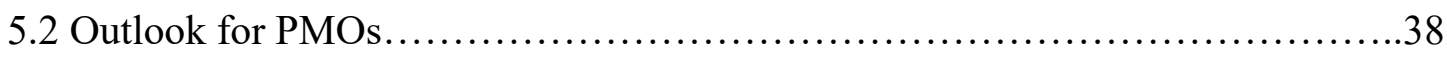

\section{Coda}

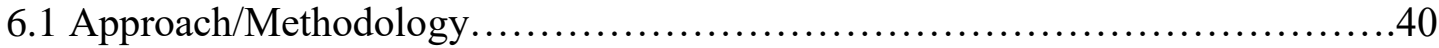

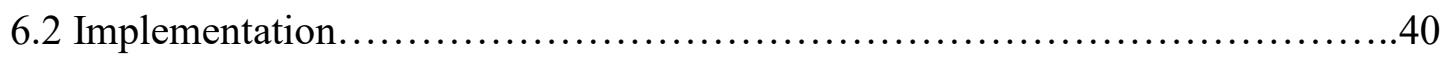

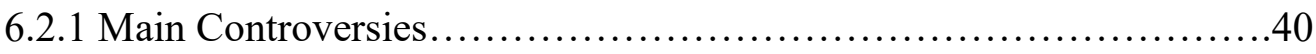

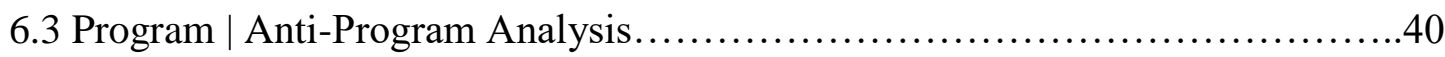

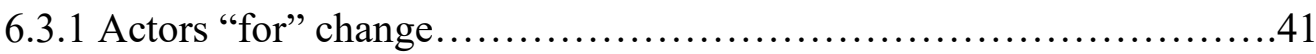

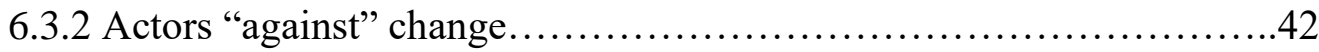

6.3.3 Socio-Technical Diagram.........................................43

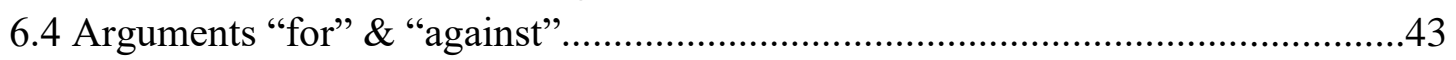

6.4.1 Arguments "for" ...............................................................................43

6.4.2 Arguments "against" ............................................................................44

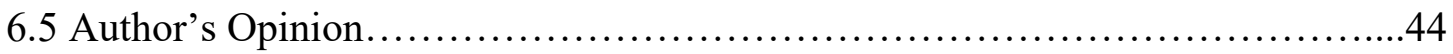

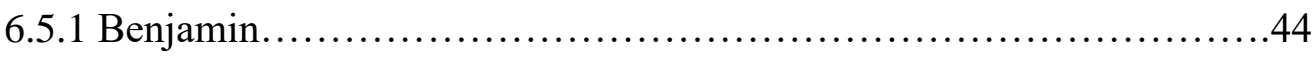

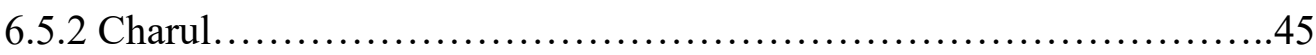

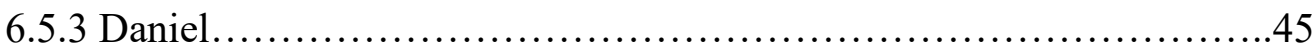

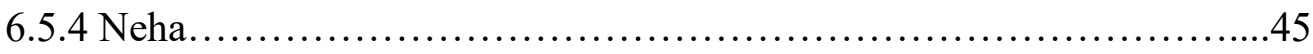

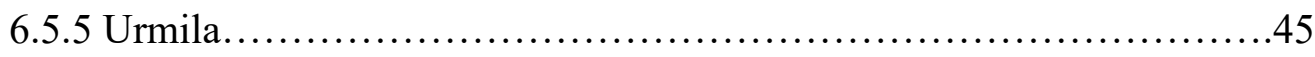

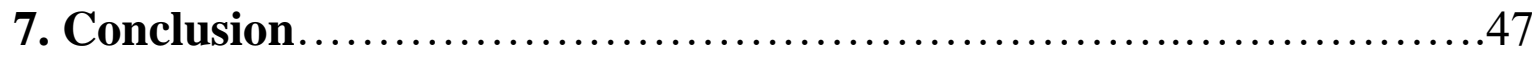




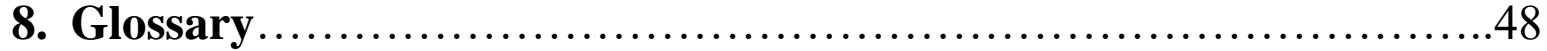

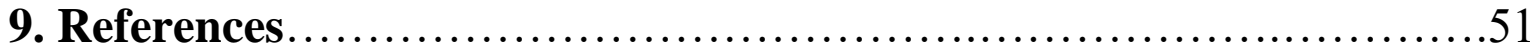




\section{EXECUTIVE SUMMARY}

Artificial intelligence and machine learning have found a wide range of business applications, but their impact is only just starting to be seen in project management. In this report, we share our findings to aid in understanding the impacts of Artificial Intelligence on projects and how they will reshape project management in the future based on suitable AI inputs.

Chapter 2 provides a brief overview of AI and attempts to break down the intricacies of its various subsets. This is accompanied by an overview of project management as prescribed by the PMI as of 2020.

Chapter 3 discusses the points of intersection between AI and project management as a profession. We show Healthcare, Transportation and Finance as three key industries more amenable to implementing AI. We also show that 8 of the 10 project processes prescribed by the PMI in the PMBOK ( $6^{\text {th }}$ edition) will be impacted to a high degree by adoption of AI. A key finding of the report where one of the conclusions we draw is that the areas least susceptible to change enforced by AI are going to be the ones which require personal relationships and human interaction. In addition, we present our findings regarding the four major AI evolutions namely - Integration and Automation; Chatbot Assistants; Machine Learning-based Project Management; and Autonomous Project Management.

Chapter 4 focuses on the points of intersection between AI and the Project Manager role. It draws and builds on from Chapter 3, and after considerable relevant literature reviews and survey meta-analysis, we share our position that the "humanness" aspect to project management is one thing that AI cannot seem to achieve. However, AI and the project manager will inevitably be interdependent; so, the project manager who wishes to remain relevant must take necessary steps to develop the right skill sets to be able to manage and complement AI capabilities.

Chapter 5 details the findings on impacts of AI on the PMO. A brief overview of the broad categories of prevalent PMO models are juxtaposed with the potential impacts of AI. Given that smart machines increasingly assume and absorb aspects of PMO work, existing PMOs will tend to amalgamate into one function concerned with change, strategy, product evolution and organizational governance by 2030 . This finding can be extrapolated as being a reflection of the massive digital transformation that IT professionals shall face in the oncoming decade.

Chapter 6 is where we culminate our findings, and where we express our own point of view. An attempt has been made to instill in the reader a sense of thrill and awe towards the oncoming decade, by utilizing the Actor Network Theory approach alongside Controversy analysis.

The most crucial aspect towards Project Management of the future resembles neither the findings from management Case Studies nor from AI. It resembles more the theory of evolution where natural selection ensures that the ones who survive will be the ones most adaptive to change, which will definitely happen.

For the curious reader who wishes to go further than the scope of our report, we suggest thinking about long term Change Management and Digital Transformation in the context of our findings. 


\section{AI \& Project Management Overview}

\subsection{AI Evolution}

AI initially started as being a pure sub-branch of computer science that aims at making computers and machines intelligent; where intelligence is restricted in the short term to mean reasoning, knowledge representation, planning, learning, natural language processing, vision and perception. In the long term view, the ambition is to achieve AGI (Artificial General Intelligence), or Strong AI as it is sometimes referred to, where the idea of intelligence involves a much more complex problematization of an amalgamation of various scientific disciplines such as mathematics, psychology, engineering etc. For the purposes of this report, we disregard AGI as the "singularity" (which is a precondition for AGI) is not anywhere near the horizon based on the consensus amongst the global AI community.

Alan Turing, considered by many as the father of modern Computer Science, published in 1950 his popular Turing test that consisted of a machine that can make conversation that is indistinguishable from a conversation with a human being [45]. If the machine passed the test, it would be labelled as "Intelligent", as per Turing. He dreamt of the day when humanity would make its Last and Final Invention. Since then, advancements in Computer Science coupled with the revolution in technology pertaining to higher processing power (thanks to Moore's Law), has made it somewhat possible for these purely theoretical musings to take some tangible shape and form.

AI has made incredible progress in the past few years. The AI of today can do specific tasks such as driving a car, booking meetings or even talking on your behalf on an audio call. All these enhancements were brought forth by AI's subsets and techniques. The following Venn diagram depicts the layers of AI as it stands today.

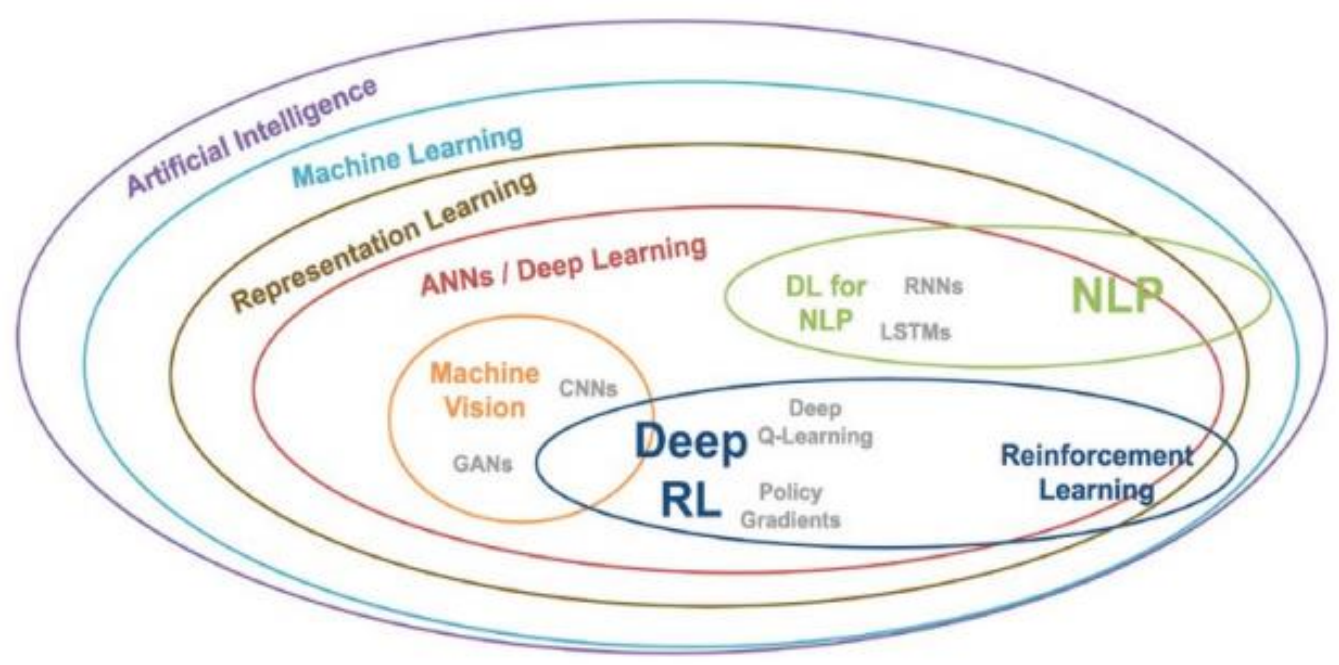

Figure 2.1: Venn diagram representing AI and its subsets. (Deep Learning Illustrated P. 86)

- Artificial Intelligence: AI can be defined as a machine that inputs data from the real world, processes it and makes specific decisions as a result in order to achieve a goal. Today's applications of AI include driving cars, chatbot, image/voice recognition, etc.

- Machine learning: ML is a subset of AI which focuses on developing software, mostly algorithms that can learn to accomplish tasks by themselves without a 
developer explicitly telling it how to. For ML to properly work it needs clean and relevant data.

- Representation Learning: RL is a branch of ML which goes deeper than Traditional ML which needs more human intervention. RL models take in huge amounts of data and learn representations also called features by themselves.

- ANNs: Artificial neural networks are the most popular RL technique. It was inspired by the human brain. It is a collection of artificial neurons that are arranged in such a way that they can send and receive information among them in order to produce the desired output.

- Deep learning: Deep learning is also an RL technique. It is made of five or more layers of artificial neurons. A single input layer takes the data, three or few hidden layers that processes the data and learn new features and a single output layer to show results.

- Machine vision: It is a branch of deep learning that focuses on object recognition. It is used for self-driving cars algorithms, image recognition and any AI that needs to at some point to recognize objects.

- NLP: Natural language processing is a machine learning technique that is used to teach the machine to recognize characters and language. Deep learning for NLP is a much efficient technique that allows AI to interact via natural languages (spoken or typed). The following diagram shows that NLP sits at the intersection of the computer science, AI and linguistics fields.

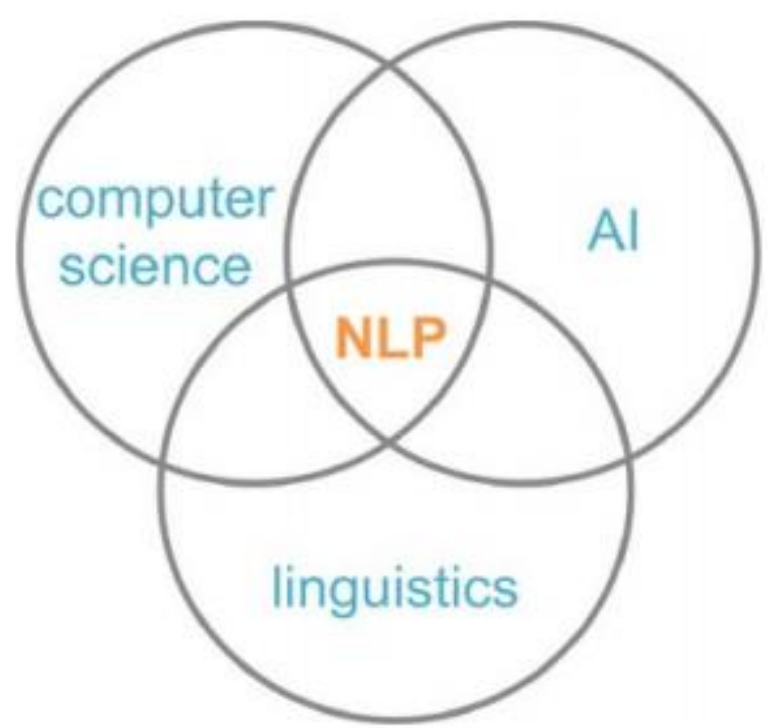

Figure 2.2: Venn diagram of Natural language processing (Deep learning illustration, p.53)

- Deep reinforcement learning: DRL is a reinforcement learning technique that involves artificial neural networks. Reinforcement learning is good at taking the appropriate decision among many options. DRL is better when it comes to processing a huge variety of data coming from an external environment.

While AI is still in the early majority phase of adoption, Kathleen Walch, in her 2019 publication "The Seven Patterns of AI" [48], reveals that probably many of the companies developing AI solutions are also the ones applying and experimenting with AI approaches to their project management. We believe that leading AI start-ups like those listed below from 
CBInsight's [49] 2020 list of top 100 AI start-ups are the best place to look for emerging practices in this field:

- Tesla: Tesla Motors was started by a group of Silicon Valley entrepreneurs and strives to create a revolution and accelerate the world's transition to electric mobility with a full range of increasingly affordable electric self-driven cars using AI, ML and Deep learning technologies. [54]

- Aurora: Aurora works at the intersection of rigorous engineering and applied machine learning to address one of the most challenging, important and interesting opportunities of our generation: transforming the way people and goods move. [50]

- Butterfly Network: It is a digital health company whose mission is to democratize healthcare by making medical imaging universally accessible and affordable. They fused semiconductor engineering, AI, and connected mobile software to achieve their vision. [51]

- Recursion Pharmaceuticals: Recursion Pharmaceuticals is a biotechnology company. It combines experimental biology, automation, and artificial intelligence in a massively parallel system to quickly and efficiently identify treatments for any disease which can be modelled at the cellular level.[52]

- C3.ai: It is a leading enterprise AI software provider for accelerating digital transformation. The C3 AI Suite supports the value chain in any industry with prebuilt, configurable, high-value AI applications for predictive maintenance, fraud detection, sensor network health, supply network optimization, energy management, anti-money laundering, and customer engagement. [53]

- Cognilytica: It is an analyst firm that provides real-world, industry and adoption focused market research, intelligence, advisory, and training on cognitive technologies including Artificial Intelligence, Machine Learning, and related areas [47].

\subsection{PMI-PMBOK Process Map}

Figure 2.3 depicts the current 'process map' of how projects are currently managed as prescribed by PMI, with the aim of simply refreshing the core ideas. Interested readers are invited to study the PMBoK v6 for their detailed analysis.

Section 3.3 discusses the impacts of AI adoption on the PMBOK processes, where the relevant ones are discussed in detail. 


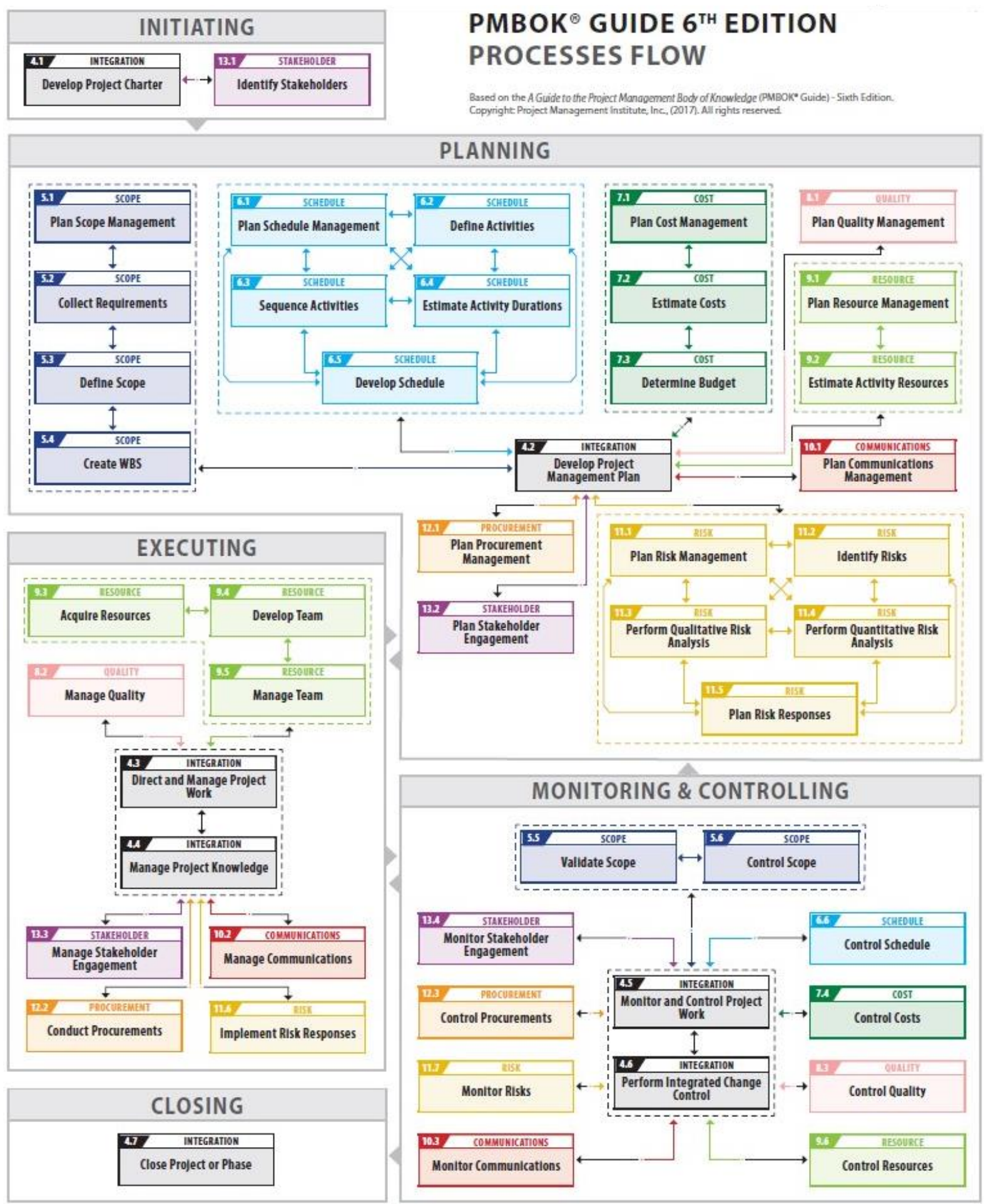

Figure 2.3: PMI Process Map (Source: Ricardo Viana Vargas: https://ricardo-vargas.com/pmbok6-processesflow/) 


\subsection{AI and PM Meta-Tables}

"From autonomous vehicles, predictive analytics applications, facial recognition, to chatbots, virtual assistants, cognitive automation, and fraud detection, the use cases for AI are many. However, regardless of the application of AI, there is commonality to all these applications. Those who have implemented hundreds or even thousands of AI projects realize that despite all this diversity in application, AI use cases fall into one or more of seven common patterns."[48]

The tables below illustrate how each of these commonalities relates to the application of artificial intelligence in project management - specifically to the process map described in section 2.2 .

Table 2.1 : Crosses AI as categorised by Forbes report and PMBOK view of phases

\begin{tabular}{|c|c|c|c|c|c|}
\hline & \multicolumn{5}{|c|}{ PMBOK PHASES } \\
\hline $\begin{array}{c}\text { FORBES 7 } \\
\text { PATTERNS OF AI }\end{array}$ & Initiating & Planning & Executing & $\begin{array}{c}\text { Monitoring and } \\
\text { Controlling }\end{array}$ & Closing \\
\hline $\begin{array}{c}\text { Hyper } \\
\text { Personnalisation }\end{array}$ & & $\mathrm{X}$ & $\mathrm{X}$ & & \\
\hline $\begin{array}{c}\text { Autonomous } \\
\text { systems }\end{array}$ & $\mathrm{X}$ & $\mathrm{X}$ & $\mathrm{X}$ & $\mathrm{X}$ & $\mathrm{X}$ \\
\hline $\begin{array}{c}\text { Predictive analytics } \\
\text { and decision } \\
\text { support }\end{array}$ & & $\mathrm{X}$ & $\mathrm{X}$ & $\mathrm{X}$ & \\
\hline $\begin{array}{c}\text { Conversational/hu } \\
\text { man interactions }\end{array}$ & & $\mathrm{X}$ & $\mathrm{X}$ & $\mathrm{X}$ & $\mathrm{X}$ \\
\hline $\begin{array}{c}\text { Patterns and } \\
\text { anomalies }\end{array}$ & & & $\mathrm{X}$ & $\mathrm{X}$ & \\
\hline $\begin{array}{c}\text { Recognition } \\
\text { systems }\end{array}$ & & $\mathrm{X}$ & $\mathrm{X}$ & $\mathrm{X}$ & \\
\hline $\begin{array}{c}\text { Goal-driven } \\
\text { systems }\end{array}$ & & & & & \\
\hline
\end{tabular}


Table 2.2 The table below depicts the relationship between 7 patterns of AI as described by Forbes and the PMBOK phases. For example, is Hyper Personnalisation visible in the Scope Management phase.

Table 2.2: The planning section of PMBOK vs FORBES AI 7 patterns

\begin{tabular}{|c|c|c|c|c|c|c|c|c|}
\hline & \multicolumn{7}{|c|}{ FORBES 7 Patterns of AI } \\
\hline & & $\begin{array}{c}\text { Hyper } \\
\text { Personna } \\
\text { lisation }\end{array}$ & $\begin{array}{c}\text { Autono } \\
\text { mous } \\
\text { Systems }\end{array}$ & $\begin{array}{c}\text { Predictive } \\
\text { Analytics } \\
\text { and } \\
\text { Decision } \\
\text { Support }\end{array}$ & $\begin{array}{c}\text { Conversati } \\
\text { onal / } \\
\text { Human } \\
\text { Interaction } \\
\mathrm{s}\end{array}$ & $\begin{array}{c}\text { Pattern } \\
\text { s and } \\
\text { Anomal } \\
\text { ies }\end{array}$ & $\begin{array}{l}\text { Recogniti } \\
\text { on } \\
\text { Systems }\end{array}$ & $\begin{array}{l}\text { Goal- } \\
\text { Driven } \\
\text { System } \\
\text { s }\end{array}$ \\
\hline & $\begin{array}{c}\text { Scope } \\
\text { Management }\end{array}$ & $X$ & & $X$ & $X$ & $X$ & & $X$ \\
\hline & $\begin{array}{c}\text { Schedule } \\
\text { Management }\end{array}$ & $X$ & $X$ & & $X$ & & $X$ & $X$ \\
\hline & $\begin{array}{c}\text { Cost } \\
\text { Management }\end{array}$ & & $X$ & $X$ & $X$ & & & \\
\hline & $\begin{array}{c}\text { Quality } \\
\text { Management }\end{array}$ & & $X$ & & $X$ & $X$ & & $X$ \\
\hline $\begin{array}{l}\mathbf{P} \\
\mathbf{M}\end{array}$ & \begin{tabular}{|c|} 
Resource \\
Management \\
\end{tabular} & & $X$ & & & & $\mathrm{X}$ & $X$ \\
\hline $\begin{array}{l}\mathbf{B} \\
\mathbf{O} \\
\mathbf{K}\end{array}$ & $\begin{array}{c}\text { Communicati } \\
\text { on } \\
\text { Management }\end{array}$ & $X$ & $\mathrm{X}$ & $X$ & $X$ & $X$ & & $\mathrm{X}$ \\
\hline & $\begin{array}{c}\text { Risk } \\
\text { Management }\end{array}$ & & $X$ & $X$ & $X$ & $X$ & $\mathrm{X}$ & $\mathrm{X}$ \\
\hline & $\begin{array}{l}\text { Procurement } \\
\text { Management }\end{array}$ & $X$ & & & & $X$ & & \\
\hline & $\begin{array}{l}\text { Stakeholder } \\
\text { Management }\end{array}$ & $X$ & $X$ & $X$ & $X$ & & $X$ & $X$ \\
\hline & $\begin{array}{c}\text { Integration } \\
\text { Management }\end{array}$ & & & & $X$ & $X$ & & $X$ \\
\hline
\end{tabular}


Table 2.3 describes the applications of AI tools and functions in different PMBOK processes. The planning section with AI tools and functions shows a more operational view.

Table 2.3: Planning section of PMBOK vs AI tools and functions

\begin{tabular}{|c|c|c|c|c|}
\hline & & \multicolumn{3}{|c|}{ AI tools and functions } \\
\hline & & Chatbot & Deep Learning & NLP \\
\hline \multirow{10}{*}{$\begin{array}{l}\mathbf{P} \\
\mathbf{M} \\
\mathbf{B} \\
\mathbf{O} \\
\mathbf{K}\end{array}$} & $\begin{array}{c}\text { Scope } \\
\text { Management }\end{array}$ & & & \\
\hline & $\begin{array}{c}\text { Schedule } \\
\text { Management }\end{array}$ & $2 \mathrm{~A}$ & & \\
\hline & $\begin{array}{c}\text { Cost } \\
\text { Management }\end{array}$ & & & $3 \mathrm{C}$ \\
\hline & $\begin{array}{c}\text { Quality } \\
\text { Management }\end{array}$ & & 4B & $4 \mathrm{C}$ \\
\hline & $\begin{array}{c}\text { Resource } \\
\text { Management }\end{array}$ & & & \\
\hline & $\begin{array}{c}\text { Communication } \\
\text { Management }\end{array}$ & $6 \mathrm{~A}$ & & $6 \mathrm{C}$ \\
\hline & $\begin{array}{c}\text { Risk } \\
\text { Management }\end{array}$ & & & \\
\hline & $\begin{array}{l}\text { Procurement } \\
\text { Management }\end{array}$ & & & \\
\hline & $\begin{array}{c}\text { Stakeholder } \\
\text { Management }\end{array}$ & $9 \mathrm{~A}$ & & $9 \mathrm{C}$ \\
\hline & $\begin{array}{c}\text { Integration } \\
\text { Management }\end{array}$ & & & \\
\hline
\end{tabular}

$2 \mathrm{~A}$ - Can schedule a meeting and manage time

6A - Chatbot can take over menial tasks such as organising meetings, listening to meetings to assign tasks to people with target dates, send out actions and follow-up.

9A - Collects details from meeting and keep track of stakeholders

4B - Analyzing component data may also help to predict which parts are likely to fail quality control.

4C - NLP is capable of identifying appropriate contents leading to quality output

6C - NLP eliminates the communication gap between human and computer

$3 \mathrm{C}$ - Reduce costs associated with manual and repetitive tasks

9C - Understands customer language to provide credible output. 


\section{AI and PROJECT MANAGEMENT}

In this chapter, we start by discussing the industries that are more susceptible to implementing AI. Then we shift our focus on how AI impacts project management in these particular industries. Next, we will analyse the PMBOK phases and their susceptibility. And finally, we discuss the existing AI tools and how they integrate to project management methodologies; as well as their risks and limitations.

\subsection{Industries amenable to implementing AI}

AI has entered various industries over the past five years. With the enterprise adoption of machine learning and deep learning algorithms, many existing sectors have witnessed widespread disruption by this new technology. As of 2020, data collection and data storage has become the norm; and sectors which have traditionally maintained well-established data banks, such as finance, healthcare, and logistics, will stand to benefit the most from an AI solution.

From the societal acceptance perspective, the general public will have to arrive at a consensus in the near future about how to measure and regulate these advances. For instance, at what point do we say that we are letting AI take over the diagnostics of a patient, or letting AI drive while we sleep comfortably behind the wheel? From a purely logical perspective, one expects that in case the frequency, rate and fatality of errors when AI is in charge is lower than what we measure when humans are in charge, then society should have no qualms in handing the reins over to AI. However, from social epistemology, an emerging precept is that overall the general public is going to be far less forgiving in case of an error if the decision making is not controlled by humans. Let us proceed to take a brief look at some industries currently working towards AI integration.

\section{- AI in Healthcare:}

The healthcare sector (as a whole) has been collecting accurate and relevant data about patients. This makes AI a good fit for the data-rich world of healthcare.

1. AI can enable easier analysis of scan results through image recognition. This has already been used to help doctors diagnose symptoms at a much higher rate, as AI can go through multiple scans much faster than humans. Even though AI has higher diagnostic accuracy, it still has to be monitored by doctors to avoid false diagnosis.

2. AI can find a variety of use-cases in the healthcare sector. Predictive analytics is expected to save $25 \%$ of healthcare cost by 2023 [38]. Using the power of predictive analytics especially machine learning algorithms, AI can help doctors make proactive moves towards ensuring their patients' health. This is a much better approach to healthcare than the reactive approach taken today.

3. By looking at the patient's financial history, as of 2020, AI can accurately predict the likelihood of an individual defaulting on a loan. This may lead to AI deciding who has access to treatment based on their insurance. 


\section{- AI in Transportation:}

As of 2019, the transportation sector has evolved where vehicles can navigate and move without any human assistance. AI in transportation helps the sector increase passenger safety, reduce traffic congestion and accidents, lessen carbon emissions, and also minimize the overall financial expenses [19].

1. Computer Vision (the precursor to autonomous navigation) is considered as one of the most revolutionary uses of AI. According to studies the global market for AI in transportation is expected to reach 3.5 billion dollars by 2023 [19]. Companies like Tesla or even Uber have already deployed autonomous vehicles in the real world. This technology can be used to facilitate the delivery of goods. An example is Tesla's semi automobile. This truck has safety features that are made possible by AI algorithms. In the future, this technology will be so advanced that humans will have to take the position of a supervisor who will only be required to monitor the AI. Major challenges in the transportation industry like capacity problems, safety, reliability, environmental pollution, and wasted energy are providing an opportunity for AI innovation [13].

2. Challenges such as flight delays in air transportation can be solved by AI. Leveraging repositories of data (Data Lakes) and Computer Vision, the industry can offer exceptional service to passengers in cutting down passenger's wait times and enhancing their journey experience by processing real-time flight data, historical records, and also the weather information. This information can help the air transportation industry glean useful insight to determine the cause of flight delays and cancellations. [19]

\section{- AI in Finance/Banking/Insurance:}

The main focus in the industry is on customer experience. Technologies like AI chatbots for rapid customer response and personalization of customer experience, RPA (Robotic process automation), Machine learning, voice recognition and Natural language processing (NLP) will be at the core of the digital transformation of the industry.

1. Compliance, IT, human resources, finance and other back-office supporting functions in the financial industry involve a lot of highly repetitive work, which is easily replaced by the application of AI to various aspects that involve risk testing, data analysis, documentary processing etc. [12].

2. Financial services have recognized the potential of AI. Analysts and experts estimate that AI will save the banking industry roughly $\$ 1$ trillion by 2030 . According to Narrative Science, $32 \%$ of the participating banks in their 2018 report are already incorporating predictive analytics, recommendation engines, voice recognition, and response times in their processes [11].

\subsection{Impact of AI on Project Management of the above Industries}

Artificial Intelligence is a complex field consisting of numerous nuances, but at the same time when used correctly, the technology can definitely increase productivity and reduce errors drastically. One of the most significant advantages of using such technology to minimize errors especially in software development projects, where you can find a variety of defects detected at any stage is an essential measure of the project quality [20]. 


\section{- Business Insights :}

AI enables project management to provide more insights into possible outcomes, which will enhance the quality of decision-making. By finding relationships and trends in data, the system will remove unnecessary information leaving management to focus on the most important information.

1. In the finance industry, organizations are at varying stages of incorporating it into their long-term organizational strategies. As companies prepare for improving their processes and working environments, it is imperative that they revisit their fundamentals goals, strengths, and weaknesses. So companies are suggested to take help of consultants in this field who can navigate business strategy. McKinsey's QuantumBlack is an example of such a firm.

Project planning could be made more robust by enabling auto-scheduling by means of programmed logic and rules [15][16]. Example, based on the (2019) PwC report progress and task status can be tracked automatically and alerting the project manager in the exception-based scenarios.

2. In the Healthcare industry, leaders can steer the next wave of progress in healthcare, by making use of advancement in data science to generate valuable insights from the large, complex data sets accruing in health systems. Machine learning algorithms can be used to provide estimates of the duration and resource requirements for project activities based on expert knowledge and lessons learned from previous projects [10].

We also have the analysis of patient data, and patient monitoring being enabled from a Machine Learning standpoint where we have companies, such as LifeMeshAI, which are experimenting with population-level data analysis to guide Public Health professionals using probabilistic modelling.

3. The rise of virtual assistants will help project managers to stay up to date on trends in their industries and help them to recruit experts to bring even more value to projects. Recommendations are a very important and useful aspect of AI. Machine learning algorithms are capable of giving recommendations on prioritising projects based on data from previous projects.

\section{- Risk Management:}

AI may not replace human judgment in the foreseeable future, but it is highly needed to support humans.

1. In the healthcare industry, for example, the execution phase of projects is quite unique. There are more layers of stakeholders who need to sign off on every step of the process. Project management in the healthcare industry involves a lot of people who could be taking care of one particular patient which makes clear that human to human communication is indispensable.

a. To cite an example a doctor relieving his duty should communicate the exact condition of a patient to the incoming doctor which if not done properly might lead to a potentially negative outcome. This is an area where AI cannot clearly come in and replace the humans involved. 
b. In an industry where patients' lives are at stake, projects cannot go overtime or over budget. Machine-learning-based project management which is a relatively new technology, can be used to make project plans to be adapted and re-baselined in near-real-time based on historical team performance and project progress.

2. In the transportation industry, the competitive threats revolve around company size and innovative capabilities. Gartner anticipates that AI will eliminate $80 \%$ of present manual project management tasks by 2030 .

3. Unlike traditional project management tools, AI can predict more accurately future issues based on previous data thereby minimizing risk. This includes risks related to people, vendors, entities etc on the project. Cost assumptions and time constraints can be examined by combining current project data with historic data to run multiple scenarios and generate, assess and rank viable outcomes [17].

\section{- Resource Allocation:}

AI can enhance Human Capital Optimization (a new form of HRMS) by calculating the best allocation of resources, Identifying the right skill for the right job, pinpointing training needed for a specific employee, predicting resources excess or shortage, providing feedback about the project manager's behaviour and competency [10]. This could be a solution to project failure which is mostly caused by teams incapable of fully grasping and/or executing a project's main goals and objectives. This in principle can also be extended to operational allocation as well, not just restricted to projects, provided that organizations maintain a detailed RACI for their employees.

According to Scott Middleton, founder and CEO of stratejos' article (3 ways AI will change project management for the better, 2017 [2]): "AI is predicted to penetrate the project management field slowly and step by step. Experts predict that AI will go through multiple generations before being fully involved in project management. these generations are explained below:

- (1st Gen) Narrow project assistants: Early project management AI will be a project assistant focused on a narrow area of managing a project or team. By focusing on supporting a team in one specific area rather than dealing with all the complexities involved in managing a project, project management AI will be useful to teams sooner rather than later.

- (2nd Gen) Expanding project understanding: As the assistants expand their understanding, new metrics will be revealed that weren't previously possible, such as quality, performance, learning, change, and effort. With more data points about projects, predictions will become more reliable, more appropriate, and easier for PMs. to understand.

- (3rd Gen) Filling in the data gaps: With new meta-data, improved data suitability, and quality, as well as a broad understanding of the various problems on projects, project management AI will be able to deliver meaningful advice." [2] to help PMs.

AI is an obvious asset from a business efficiency perspective, due to its ability to manage complex analytics. It allows a program to track how a project progresses, and to make informed assumptions about the project's future. 
AI has the ability to do the following [37]:

- AI's ability to track human beings and make predictions based on the trends it sees is a more nuanced capacity. It is capable of tracking budgets and scheduling and can learn to recognise possible impacts on them over time.

- AI systems can observe projects and behaviour of individual team members and can pick up certain habits and nuances with team members that could otherwise be overlooked.

- AI can recognize when something is happening that is likely to lead to scheduling conflicts and makes it possible to offer suggestions on alternate dates of completion if the scheduling is off course.

- Ensures that the program can help provide customized guidance based on acquired habits for employees. Some day these systems could account for the conflicts with a remote employee working in a different time zone and make educated adjustments based on that.

- AI systems can go as far as identifying when someone is doing something out of compliance, which opens them up to the possibility of recognizing potential instances of fraud and other types of issues that could arise.

\subsection{PMBOK Phases \& Their Susceptibility}

The 'Initiating' phase of the PMBOK version 6, of which sub-process 4.1 (Develop Project Charter) is a major part, has its overall value in ensuring that there is a direct link between the project and the strategic objectives of the organization. Thereby ensuring that the project has a high probability of success. This brings up the all-important question of what exactly constitutes project success: are there specific project objectives with related success criteria that are quantifiable? Enter AI.

As specified in the PMBOK [39], the most important tools at the core of most of the processes are expert judgment, followed closely by data gathering and data analysis.

Fernández-Rodríguez and Martinez [26] show two main flaws in Expert Judgement -

- Requirement of high accuracy in complex projects leading to difficulty for application of expert judgement.

- Expert judgement being itself prone to human error, for eg. Bias.

Similarly, data gathering is also susceptible to human input. For instance, "initial lack of experience and knowledge when managing new projects that may have an unfamiliar scope or unique challenges will impact the quality of data" [40]. This does not bode well for success, and presents an opening for potential remedies in AI.

As alluded to in the previous section, AI is most notably already impacting project management in its ability to remove project risk and uncertainty in project planning, and execution.[42] These are some of the key areas where artificial intelligence will have the biggest impacts.

Now we will go into individual processes/phases/subprocesses of the PMBOK to ascertain specific impacts :

1. Project Integration Management (PMBOK v6, Chapter 4): At the heart of every PMBOK project phase, aiming primarily to unify and coordinate the various processes and activities within each process group, the bulk of activities that make up 
the integration process revolves around collection and consolidation of data from other processes, analysing this data and outputting useful information and insights to inform decision making and activities. This description is the hallmark of AI and Data Science, hence this is probably where we expect to see some of the biggest and more immediate impacts of artificial intelligence.

Martínez and Fernández-Rodríguez [26] demonstrated that AI can not only be extremely useful in identifying critical success factors of a project but can go even further to predict its success (or failure) right from the very early stages, through the application of specific AI algorithms. This is detailed in sub-section 3.4 of this report. This means that better decisions can be made about whether to proceed with a project and what, if any, changes need to be made if indeed a decision is made to proceed. While these are very promising applications of machine learning, literature from PWC [41] confirms currently only a few examples of the successful integration of machine learning in project management exist. It goes on to suggest that, all things being equal, these applications should be more commonplace by the year 2030 and beyond.

2. Subprocess 4.2 (Develop Project Management Plan) which unifies data input from all other planning processes to output a comprehensive plan, has already begun to see the valuable impacts of AI through integration and automation technologies and AI chatbots.

Integration and automation technologies have enabled interaction between MS Project Online and Wunderlist for task creation and scheduling, for instance. This is a good indicator of how AI will infiltrate all of the integration sub-processes. These AI applications are already being adopted by and creating immense value for many organisations, and we expect that they would be commonplace within the next 5 years.

3. Project Quality Management (PMBOK v6, Chapter 8): A project management Quality Compliance Methodology PWC [40] consisting of numerous checkpoints covering specific quality compliance areas was developed and used to monitor and manage over 60 client projects, capturing and storing the resultant data over 2 years. This methodology was subsequently automated using AI \& RPA, in the form of a virtual assistant robot, to check the compliance levels of a sample set of projects. The results were :

a. The robot was successfully and accurately able to analyse this project data, evaluate each project's compliance levels, provide recommendations on improving quality, and redefine the scope for subsequent compliance checks.

b. All these insights were presented in a comprehensive executive style dashboard report fully created by the robot, which also autonomously shared these reports to the appropriate stakeholders immediately via email, as well as through its own interface (See figure 3.1). 


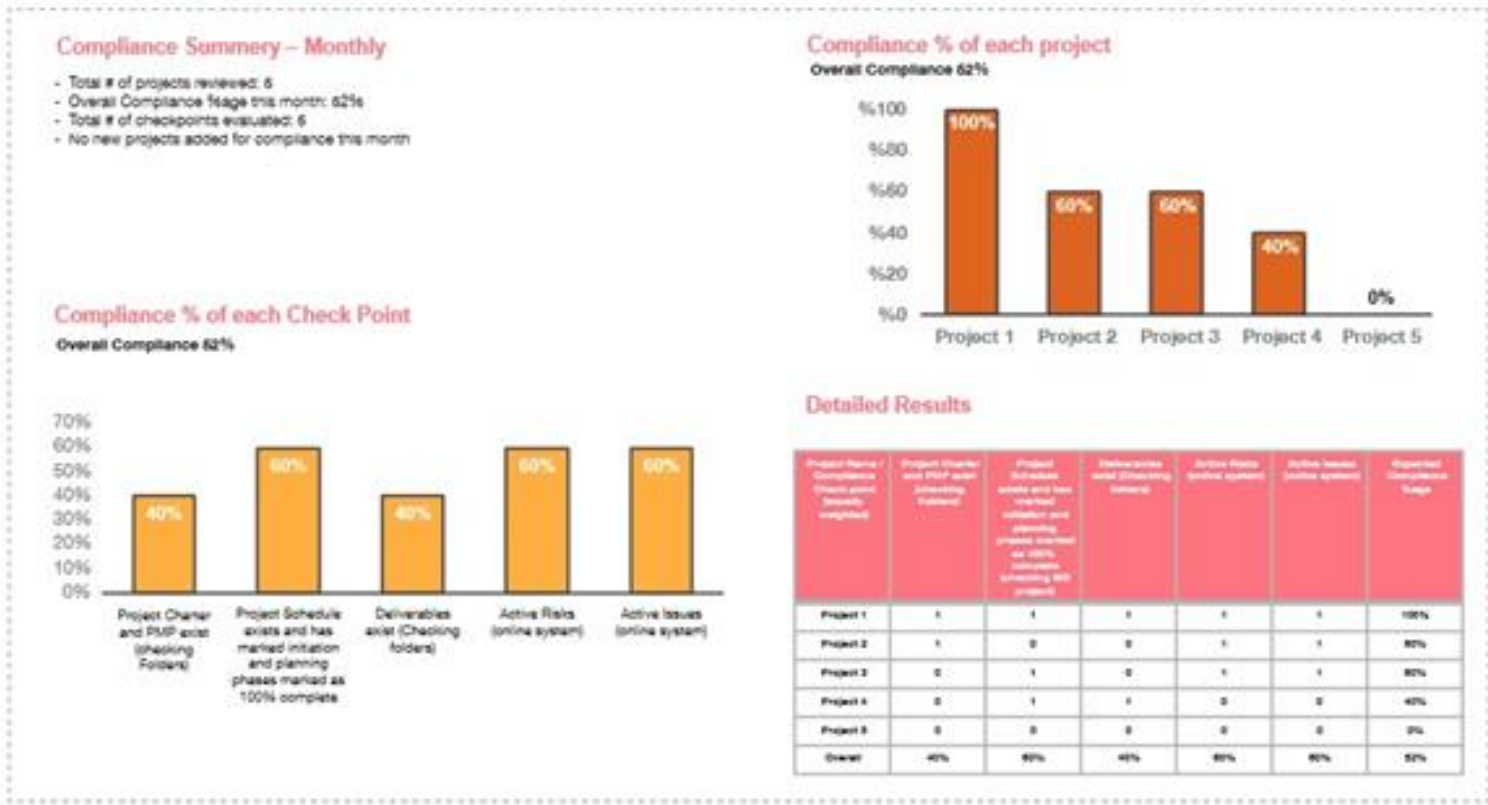

c. From the reference [40] "the estimated time, based on the team's experience, for a human to perform a compliance check of similar size is around three days. These checks are naturally prone to human error, and timely communication and reporting is always a challenge. The robot performed the same task, accurately and effectively, in up to six minutes."

4. Project Communications Management (PMBOK v6, Chapter 10): PWC [41] describes how "chatbots can take over menial tasks such as organising meetings, plan vs progress checks, reminding project team members of scheduled activities" and go a step further by "listening to meetings to assign tasks to people with target dates, send out actions and follow-up" [40].

They describe a few current real-life use cases which are summarised in table 3.1. While the communication management transformation is in full progress with integration and automation technologies and chatbots being implemented by many organisations, the impacts on quality management, with these arising from the adoption of machine learning, are expected to fully materialize within the next 5-10 years.

Table 3.1: AI chatbot, integration and automation use cases.

\begin{tabular}{|l|l|}
\hline \multicolumn{1}{|c|}{ AI Integration \& Automation } & \multicolumn{1}{c|}{ AI Chatbots } \\
\hline $\begin{array}{l}\text { Using online templates and workflows, } \\
\text { e.g. in Slack or MS Sharepoint, to } \\
\text { reduce time and enhance the quality of } \\
\text { data }\end{array}$ & $\begin{array}{l}\text { Fireflies.ai is an AI bot for Slack that processes } \\
\text { conversations within Slack and recognises tasks } \\
\text { and assignments on this basis }\end{array}$ \\
\hline $\begin{array}{l}\text { Sending alerts when potential budgeting } \\
\text { or scheduling issues are identified for } \\
\text { the project }\end{array}$ & $\begin{array}{l}\text { Stratejos.ai sends team members reminders, } \\
\text { tracks their performance, and enables the project } \\
\text { manager to recognise top contributors based on } \\
\text { measurables }\end{array}$ \\
\hline
\end{tabular}


5. Project Schedule Management; Project Cost Management; Project Resource Management; Project Risk Management (PMBOK v6, Chapters 6; 7; 9; 11): Artificial intelligence also promises huge impacts on risk management, scheduling, budgeting, and resource management. As detailed in section 3.4 of this report, predictive analysis and forecasting are two of the core capabilities enabled by artificial intelligence - through machine learning algorithms precisely.

6. Stakeholder Management; Project Scope Management (PMBOK v6, Chapters 5; 13): These processes appear to be much less susceptible to AI for similar reasons. While the activities in sub-processes 13.1 (identify stakeholders) and 13.4 (monitor stakeholder engagement), for instance, can mostly be taken over by AI, those of subprocesses 13.2 and 13.3 (planning and managing stakeholder engagement, respectively) simply cannot. The human elements required to understand stakeholders' interests, needs, expectations and issues - interpersonal skills, emotional intelligence, active listening, among others - cannot be replicated by machines.

In the same vein, the skills required to effectively elicit requirements from and negotiate scope with clients is something a machine does not possess yet.

If at some point in the future, technology advances to the level where this becomes possible, we would then be ushering in the fourth phase of AI evolution in project management not dissimilar to self-driving cars - autonomous project management - requiring little intervention from humans. PWC [41] literature explains that "these AI systems would, therefore, have to be able to apply sentimental analysis algorithms to crawl through customer communications and understand stakeholder satisfaction and commitment at any given point in time." In the same breath, however, they confirm that there are currently no real-life cases of this in action, neither are any expected looking even 20 years ahead.

\subsection{Existing AI \& PMI Methodology}

Dam et al. (2018) [24] envision that AI will transform (software) project management practice in many aspects, from automating basic administration tasks to delivering analyticsdriven risk predictions and estimation, facilitating project planning and making actionable recommendations. Popular methodologies like Agile will be without a doubt transformed in the way they are implemented.

According to a survey conducted among 56 project managers from different industries made by (BUTT, 2018 as cited in Elrajoubi, 2019 [25]), the following aspects of project management with the highest responses can be supported by AI. 


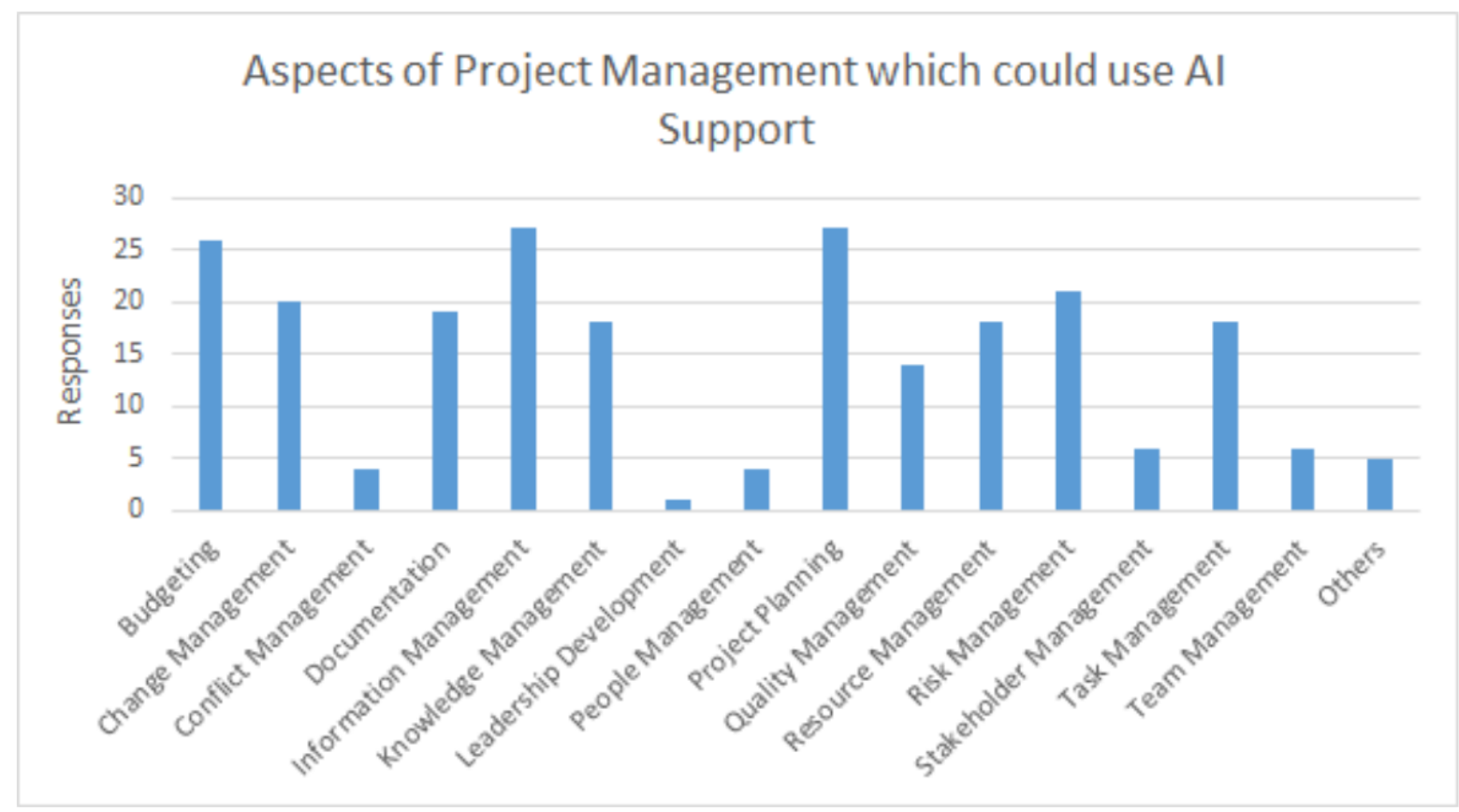

Figure 3.2: Areas where AI support can be used for project management (BUTT, 2018 as cited in Elrajoubi, 2019)

Processes such as project planning are one of the most important tasks of the project manager. It consists of planning and laying out the work breakdown structure (WBS) of the project. Machine learning algorithms can be used to automatically convert the WBS into mind maps and further extract WBS tasks and the relationship between them. We will discuss some of these areas below, while mapping onto the PMI frameworks as much as possible.

1. Planning and Budgeting (Planning) : Martínez, Fernández-Rodríguez (2015 [26]) used two models based on neural networks and Support Vector Machines. As cost and schedule indicators have important differences, the authors have developed two different models, one for each indicator.

a. For costing, the authors' conclusion is that the best is SVM (Support Vector Machine) with an accuracy of $92 \%$, followed by Adaptive Boosting and finally Bootstrap Aggregating.

b. For scheduling, the results are slightly worse. With a rate of $80 \%$ corresponding to Adaptive Boosting followed by SVMs and Bootstrap Aggregating.

Martínez, Fernández-Rodríguez (2015 [25]) mentioned that some of the reviewed models have weaknesses and limitations that indicate project managers should still use expert judgement and compare artificial intelligence results with traditional tools before making a decision, so they can adjust them if necessary.

2. Project Status Reporting (Monitoring and Controlling) : Knowing if a project is well managed and is going to be successful, is every project team's main prerogative and duty. We base the following comments on Martínez, Fernández-Rodríguez (2015 [26]), who demonstrated the application of AI algorithms to predict project success based on the traditional project success criteria - scope, time, budget and quality. These traditional success criteria, however, leave aside other qualitative aspects of 
project management, for example the stakeholders' point of view. The paper also points out the following:

a. that a satisfactory definition of project success/failure has not been made, and they attribute this as one of the main reasons why project status is much more challenging than one may intuitively assume.

b. New key indicators proposed by various industry studies for measuring project success (see table 3.2).

\begin{tabular}{|l|c|c|}
\hline & $\begin{array}{c}\text { TRADITIONAL } \\
\text { CRITICAL SUCCESS } \\
\text { FACTORS }\end{array}$ & $\begin{array}{c}\text { PROPOSED CRITICAL } \\
\text { SUCCESS FACTORS }\end{array}$ \\
\hline $\begin{array}{l}\text { Triple constraints: scope, } \\
\text { time, budget }\end{array}$ & $\mathrm{X}$ & $\mathrm{X}$ \\
\hline Stakeholder satisfaction & & $\mathrm{X}$ \\
\hline Project safety & & $\mathrm{X}$ \\
\hline Project performance & & $\mathrm{X}$ \\
\hline Project impact on business & & \\
\hline
\end{tabular}

Table 3.2: Traditional CSFs against Proposed CSFs to predict project success rate

They applied a Bayesian model to classify different metrics collected from a project's early state to make an estimation on project success rate using statistical methods to improve the accuracy of results. The model was fed with data from 28 software development projects. This requires explanation, as to what precise metrics are fed into a probabilistic model which can help in reporting, and that too specifically when it comes to reporting on the newly proposed CSF above.

3. Project Estimation (Planning): Evolutionary Project Success Prediction Model (EPSPM) fuses several AI algorithms - genetic algorithms (GAs) for optimization, fuzzy logic (FL) for reasoning and neural networks (NN) for mapping inputs and outputs.

EPSPM is integrated with the Continuous Assessment of Project Success tool [55]. It is a technique that can be applied to any kind of project,and allows project teams to predict estimates by choosing specific critical success factors related to the project life cycle phase.

\begin{tabular}{|l|l|l|}
\hline \multicolumn{1}{|c|}{ ALGORITHM } & \multicolumn{1}{c|}{ STRENGTH } & \multicolumn{1}{c|}{ WEAKNESS } \\
\hline $\begin{array}{l}\text { GA (Genetic Algorithm) : } \\
\text { - based on darwin's theory of } \\
\text { evolution }\end{array}$ & $\begin{array}{l}\text { Best for generating high- } \\
\text { quality solutions for } \\
\text { optimization }\end{array}$ & $\begin{array}{l}\text { Not suited for simpler problems } \\
\text { where the derivative information } \\
\text { is readily available }\end{array}$ \\
\hline $\begin{array}{l}\text { FL (Fuzzy Logic) : } \\
\text { - for reasoning, } \\
\text { - employed to handle the } \\
\text { concept of partial truth (where }\end{array}$ & $\begin{array}{l}\text { Suitable for dealing with } \\
\text { imprecise or inaccurate } \\
\text { values }\end{array}$ & $\begin{array}{l}\text { Requires a huge amount of data } \\
\text { and very high mathematical } \\
\text { expertise }\end{array}$ \\
\hline
\end{tabular}




\begin{tabular}{|l|l|l|}
\hline $\begin{array}{l}\text { the truth-value may range } \\
\text { between completely true and } \\
\text { completely false.[10]) }\end{array}$ & \\
\hline $\begin{array}{l}\text { NN (Neural Networks) : } \\
\text { - based on the human brain, } \\
\text { - to recognize a pattern in large } \\
\text { sets of data, } \\
\text { - for mapping inputs and outputs }\end{array}$ & $\begin{array}{l}\text { Able to process huge amount } \\
\text { of data and find patterns } \\
\text { without human intervention }\end{array}$ & $\begin{array}{l}\text { Requires a huge amount of data } \\
\text { and a high-level infrastructure to } \\
\text { perform compared to other deep } \\
\text { learning algorithms }\end{array}$ \\
\hline
\end{tabular}

4. Agile Methodologies: Dam et al. (2018 [24]) explain how Agile project management can be assisted and how to increase the rate of successful projects with the use of an AI-based Agile project assistant.

a. The core of this AI system is an analytics engine, a planning engine and an optimization engine. These machineries depend on the learning representation engine to learn and generate representations of project data that are mathematically and computationally convenient to process [24].

b. This means that the system is designed to take raw, unstructured data of projects from the real world and make the data readable in order to be fed to the algorithms that will bring new business value to the project.

c. Product owner in charge of the backlog and items tracking will have less to do since the system will be able to classify and prioritize items.

d. With NLP (Natural Language Processing) at the core and other machine learning and deep learning techniques, the system can enhance the "Why" (Descriptive analytics), the "When" (Predictive analytics) of an event and based on the descriptive and the predictive analysis, recommends (Prescriptive Analytics) the best course of actions for agile teams in a specific situation [24]. Integrating such a system to current project management is not an easy task. However, this system could take care of a lot of administrative and core aspects of a project. 


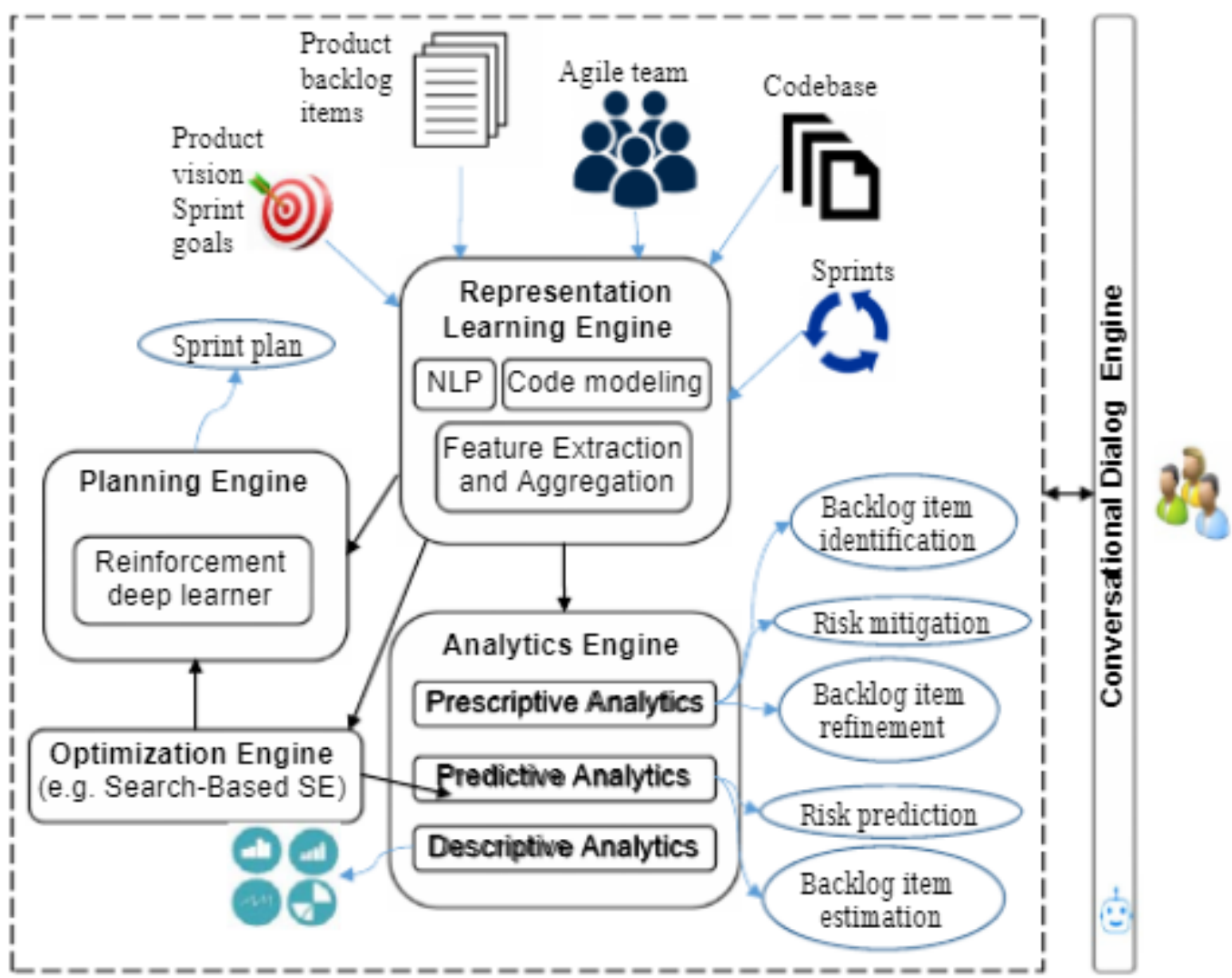

Figure 3.3: The architecture of an AI-powered agile project management assistant (Dam et al. , 2018)

The use of AI in project management is not only transforming the way projects are managed and implemented. It also pushed professionals to develop a new methodology to correctly implement AI-based projects.

Cognilytica has worked with dozens of organizations and through hundreds of real-world implementations to develop a methodology optimized for the delivery of in-production, high value, low risk AI projects [27]. CPMAI extends the well-known CRISP-DM (Cross Industry Standard Process for Data Mining) methodology with AI and ML specific documents, processes, and tasks. The CPMAI methodology also incorporates the latest practices in Agile Methodologies and adds additional DataOps activities that aim to make CPMAI data-first, AI-relevant, highly iterative, and focused on the right tasks for operational success [27]. The core elements of the CPMAI methodology are as shown in figure 3.4. 


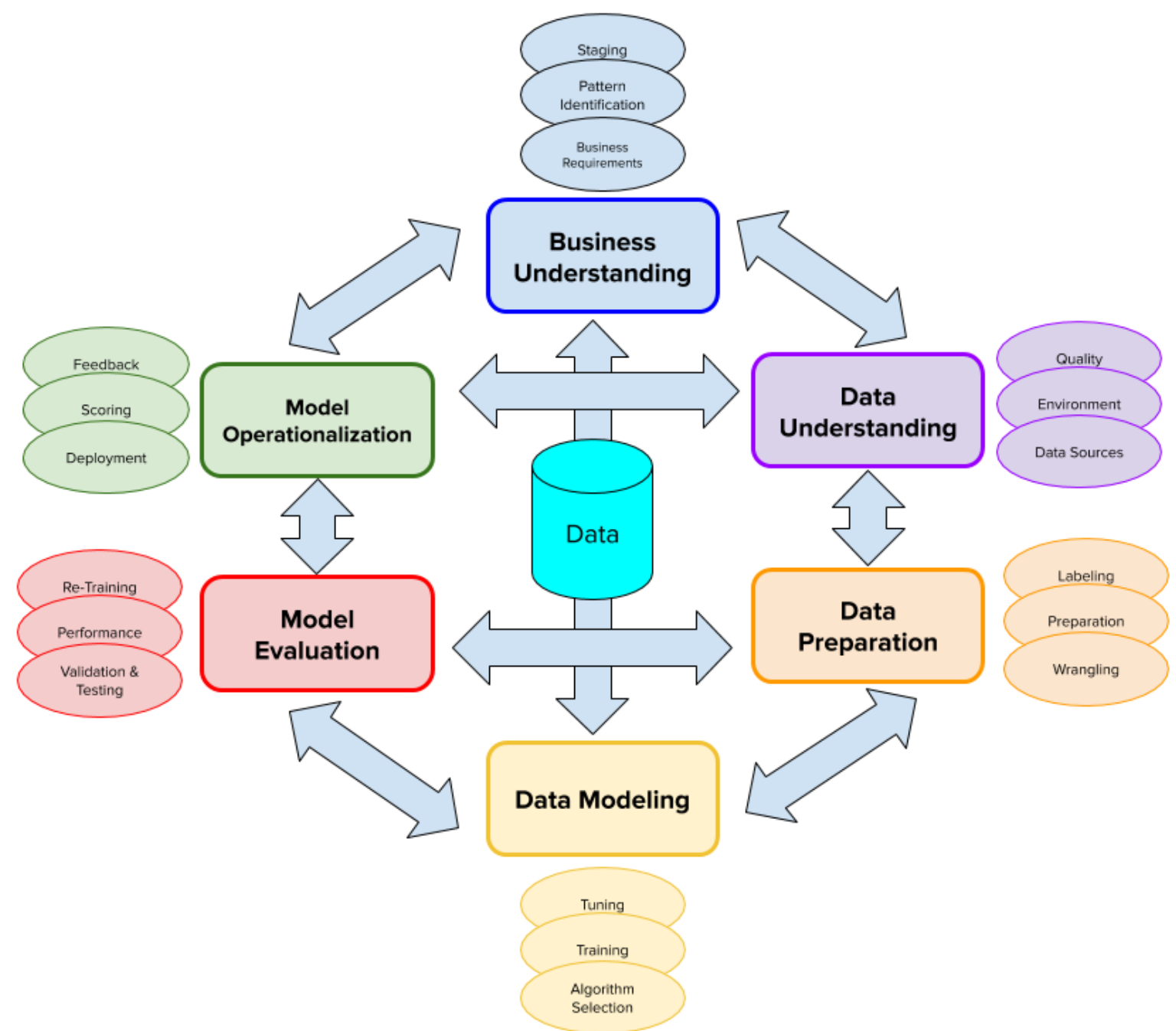

Figure 3.4: Core Element of CPMAI Methodology [27]

\subsection{Risks \& Limitations of AI in Project Management}

The technologies are increasingly improving the productivity, profitability and business results, but there are also certain barriers and limitations to be taken care of. (Russell 2017 [46]) have discussed the key dimensions of AI risks, tabulated here:

\begin{tabular}{|c|l|l|}
\hline Risk dimensions & \multicolumn{1}{|c|}{ Description } & \multicolumn{1}{|c|}{ Impact on PM } \\
\hline Security & $\begin{array}{l}\text { AI technology may not follow the } \\
\text { company's security standards. }\end{array}$ & $\begin{array}{l}\text { Depending on the desired output } \\
\text { of the project, AI can endanger } \\
\text { the safety of human beings. }\end{array}$ \\
\hline Privacy & $\begin{array}{l}\text { AI cannot appropriately distinguish } \\
\text { between approved and restricted data } \\
\text { and violates the right to privacy. }\end{array}$ & $\begin{array}{l}\text { This can promote collecting } \\
\text { personal data, unauthorised } \\
\text { recordings and making unethical } \\
\text { decisions. }\end{array}$ \\
\hline
\end{tabular}




\begin{tabular}{|c|l|l|}
\hline Autonomy & $\begin{array}{l}\text { As AI dominates the environment, it } \\
\text { may make people feel like 'slaves' } \\
\text { to the machine. }\end{array}$ & $\begin{array}{l}\text { AI at a certain point becomes } \\
\text { independent which makes } \\
\text { Project Managers lose track of } \\
\text { how and when to stop AI [23]. }\end{array}$ \\
\hline $\begin{array}{l}\text { Data Quality/ } \\
\text { Availability }\end{array}$ & $\begin{array}{l}\text { Incomplete and missing data reflects } \\
\text { the statistical power of a prediction } \\
\text { and produces estimates leading to } \\
\text { invalid conclusions. }\end{array}$ & $\begin{array}{l}\text { Managing a set of stakeholders } \\
\text { and various unpredictable events, } \\
\text { AI-led projects will mostly fail to } \\
\text { react appropriately to these } \\
\text { challenges. }\end{array}$ \\
\hline Employment & $\begin{array}{l}\text { Repetitive and low skilled jobs } \\
\text { might no longer be available. }\end{array}$ & $\begin{array}{l}\text { AI may not be competent to } \\
\text { assign a task to the right person } \\
\text { as it lacks people and social } \\
\text { skills. }\end{array}$ \\
\hline
\end{tabular}

Table 3.4: Dimensions of AI risk

According to Scott Middleton, founder and CEO of stratejos' article (3 ways AI will change project management for the better, 2017 [2]), here are some challenges AI will face while integrating in Project management, as well as some recommended solutions for said challenges:

\begin{tabular}{|l|l|}
\hline \multicolumn{1}{|c|}{ Challenges faced by AI } & \multicolumn{1}{|c|}{ Solutions to overcome Challenges } \\
\hline $\begin{array}{l}\text { The quality and suitability of the data about } \\
\text { project management tools. }\end{array}$ & $\begin{array}{l}\text { Encouraging better practice: AI can gently } \\
\text { encourage teams to improve the quality of } \\
\text { the data they are inputting (such as chat }\end{array}$ \\
$\begin{array}{l}\text { Early, narrow project management AI tools } \\
\text { rely on people to input data correctly, update } \\
\text { tools in a timely manner, and make } \\
\text { corrections. }\end{array}$ & $\begin{array}{l}\text { apps). that cannot be automated. } \\
\begin{array}{l}\text { In any project management system or or may not be able to display a } \\
\text { toolset, there is missing data or messy, } \\
\text { unstructured data. }\end{array}\end{array}$ \\
\hline
\end{tabular}

As with any other technology, there are limitations and AI is no exception. A big hindrance to AI adoption is the skills deficit and the availability of experienced technical staff and training to deploy and operate AI solutions.

1. Data inconsistency: exists where data sources conflict with each other at the data value level because the same data exists in different formats in multiple tables. Welldesigned and controlled project management environment, missing or incomplete data occurs in almost all areas. Incomplete data can reduce the statistical power of a prediction and produce estimates leading to invalid conclusions[28].

2. Creativity: Machines simply lack the ability to be creative. Humans can think and feel, hence decision making is creative and will benefit the output. AI can definitely assist in terms of helping to determine the sort of imagery with likely customer preference style and price. But a machine cannot compete with the human brain yet 
when it comes to originality. AI can be coached on some parameters of creativity which can develop its own sense of creativity [29].

3. Hiring and Retention: As the field is quite new in the area of project management companies may have to invest in upskilling their employees to meet the demands and challenges of this new mode of Project management.

\begin{tabular}{|c|c|c|c|c|c|}
\hline$\underset{\text { term/tool }}{\text { AI }}$ & Function(s) & Possible effect & Example(s) & Comments & Horizon \\
\hline $\begin{array}{l}\text { Natural } \\
\text { language } \\
\text { processing } \\
(\mathrm{NLP})\end{array}$ & $\begin{array}{l}\text { AI technology to } \\
\text { extract and } \\
\text { understand human } \\
\text { language. }\end{array}$ & $\begin{array}{l}\text { NLP can be used } \\
\text { to identify real- } \\
\text { world items in } \\
\text { the project } \\
\text { backlog and } \\
\text { automatically } \\
\text { determine, } \\
\text { classify and } \\
\text { prioritize items. }\end{array}$ & $\begin{array}{l}\text { Understand } \\
\text { people's } \\
\text { communication } \\
\text { styles and adapt } \\
\text { to them }\end{array}$ & $\begin{array}{l}\text { - High maturity } \\
\text { - Significant } \\
\text { adoption \& } \\
\text { industry } \\
\text { application }\end{array}$ & Now \\
\hline $\begin{array}{l}\text { Automation } \\
\& \text { Integration }\end{array}$ & $\begin{array}{l}\circ \text { Administrative } \\
\text { project planning } \\
\text { - Integration } \\
\text { activities }\end{array}$ & $\begin{array}{l}\text { Takes over } \\
\text { most repetitive } \\
\text { processes. }\end{array}$ & $\begin{array}{l}\text { - Using online } \\
\text { templates and } \\
\text { workflows } \\
\text { o Integrating } \\
\text { data from } \\
\text { multiple } \\
\text { sources for task } \\
\text { creation and } \\
\text { scheduling }\end{array}$ & $\begin{array}{l}\text { - Medium } \\
\text { maturity } \\
\text { - Significant } \\
\text { adoption already } \\
\text { underway }\end{array}$ & $5-10$ years \\
\hline $\begin{array}{l}\text { Chatbot } \\
\text { Assistant }\end{array}$ & $\begin{array}{l}\text { - PM support: } \\
\text { monitoring } \\
\text { ○ Communication }\end{array}$ & $\begin{array}{l}\text { Takes over } \\
\text { most repetitive } \\
\text { activities/proce } \\
\text { sses. }\end{array}$ & $\begin{array}{l}\circ \text { AI bot } \\
\text { processes } \\
\text { conversations } \\
\text {-Recognises } \\
\text { and } \\
\text { communicates } \\
\text { tasks on this } \\
\text { basis }\end{array}$ & $\begin{array}{l}\text { - Medium } \\
\text { maturity } \\
\text { - Significant } \\
\text { adoption \& } \\
\text { industry } \\
\text { application } \\
\text { already } \\
\text { underway }\end{array}$ & $5-10$ years \\
\hline $\begin{array}{l}\text { Machine } \\
\text { Learning- } \\
\text { Based PM }\end{array}$ & $\begin{array}{l}\text { - Decision } \\
\text { making support } \\
\text { (monitoring, } \\
\text { controlling \& } \\
\text { execution } \\
\text { support) } \\
\text { - Data analysis } \\
\text { - Scheduling } \\
\text { - Risk } \\
\text { management }\end{array}$ & $\begin{array}{l}\text { - Complements } \\
\text { PM's other } \\
\text { tools } \\
\text { o Supports PM } \\
\text { processes/activi } \\
\text { ties }\end{array}$ & $\begin{array}{l}\text { RPA bot } \\
\text { monitors } \\
\text { assesses and } \\
\text { reports on } \\
\text { project quality, } \\
\text { risks } \\
\text { - Suggests } \\
\text { action points } \\
\text { for quality } \\
\text { compliance, } \\
\text { risk mitigation }\end{array}$ & $\begin{array}{l}\text { - Low maturity } \\
\text { ॰ Generally still } \\
\text { at PoC stage, } \\
\text { sporadic } \\
\text { industry } \\
\text { application }\end{array}$ & $10+$ years \\
\hline
\end{tabular}




\begin{tabular}{|c|c|c|c|c|c|}
\hline $\begin{array}{l}\text { Autonomous } \\
\text { PM }\end{array}$ & $\begin{array}{l}\text { - Complete } \\
\text { project } \\
\text { management } \\
\text { - Data gathering } \\
\& \text { analysis } \\
\text { - Stakeholder } \\
\text { management... }\end{array}$ & $\begin{array}{l}\text { Virtually } \\
\text { replaces human } \\
\text { PM as is }\end{array}$ & $\begin{array}{l}\text { Applying } \\
\text { sentimental } \\
\text { analysis } \\
\text { algorithms to } \\
\text { crawl through } \\
\text { customer } \\
\text { communication } \\
\mathrm{s} \text { and } \\
\text { understand } \\
\text { stakeholder } \\
\text { satisfaction and } \\
\text { commitment }\end{array}$ & $\begin{array}{l}\text { No noteworthy } \\
\text { applications } \\
\text { yet... }\end{array}$ & $\begin{array}{l}\text { Not in } \\
\text { foreseeable } \\
\text { future }\end{array}$ \\
\hline
\end{tabular}

Table 3.5: Summary of AI impacts on Project Management (all entries in this table are from a highly reliable source: PWC [40], [41]) 


\section{AI AND PROJECT MANAGER}

\subsection{Introduction}

Thanks to AI, PMs will be able to devote more time to strategic and tactical thinking and judgment since repetitive tasks and routines can be automated. This would mean that a PM will focus on more value-added activities. As AI becomes more effective, project managers will rely on the decisions of the machines that:

- Will advise future trends,

- Automate time scheduling,

- Respond to requests coming from superiors and staff.

Such frameworks integrate with common collaboration tools such as Slack, as well as project management software such as JIRA to make it more effective when it comes to problem solving.

Studies have shown that project managers spend more than half of their time on administrative tasks such as dealing with check-ins and managing updates.

The following include ways AI adds value to the role of a Project Manager:

- AI frees up time for project managers to focus on strategic-level goals and planning.

- AI may appear to be a threat to job security, but it may instead increase the value that project management professionals can bring to the table.

- AI helps companies achieve long-term objectives successfully by further solidifying the significance of roles by adding value to them.

AI bots are capable of stepping up and handling these less intensive tasks for the project manager with current systems cutting time spent on busy work in half. This is a big timesaver, enabling project managers to:

- Concentrate more on the dynamic processes behind their strategic management.

- To focus more time on their employees, which in turn can help them empower their employees and find further efficiencies.

- Such managers will concentrate more on what matters to them with the time saved using AI-enabled project management systems.

- Make the work atmosphere more relaxed where workers feel valued and realize they have the necessary resources in place.

When it comes to project management team leaders, a primary advantage for AI devices, at least for now, is the fact that they can save time on busywork. A considerable amount of time is placed into record-keeping, recording, and various other remedial activities for most of the employees. This also makes the entire process more effective, which in effect will save time and budget expenses by allowing workers to concentrate on the tasks that really matter.[4]

\subsection{Impact of AI on Project Managers}

Considering that AI acts as a project management's 'virtual partner'; project leaders must have an innovative mindset and customize their knowledge to drive this digital transformation forward. Having strong 'digital know-how' and data science skills is key, alongside security and privacy knowledge. The legal and regulatory knowledge to manage contracts is also important. AI and project managers will have to collaborate in the digital era. 
As awareness of the profession continues to increase, it is expected that a greater proportion of project work will earn more distinct attribution for the profession itself, giving more recognition and appreciation to the role of the project manager.[33]

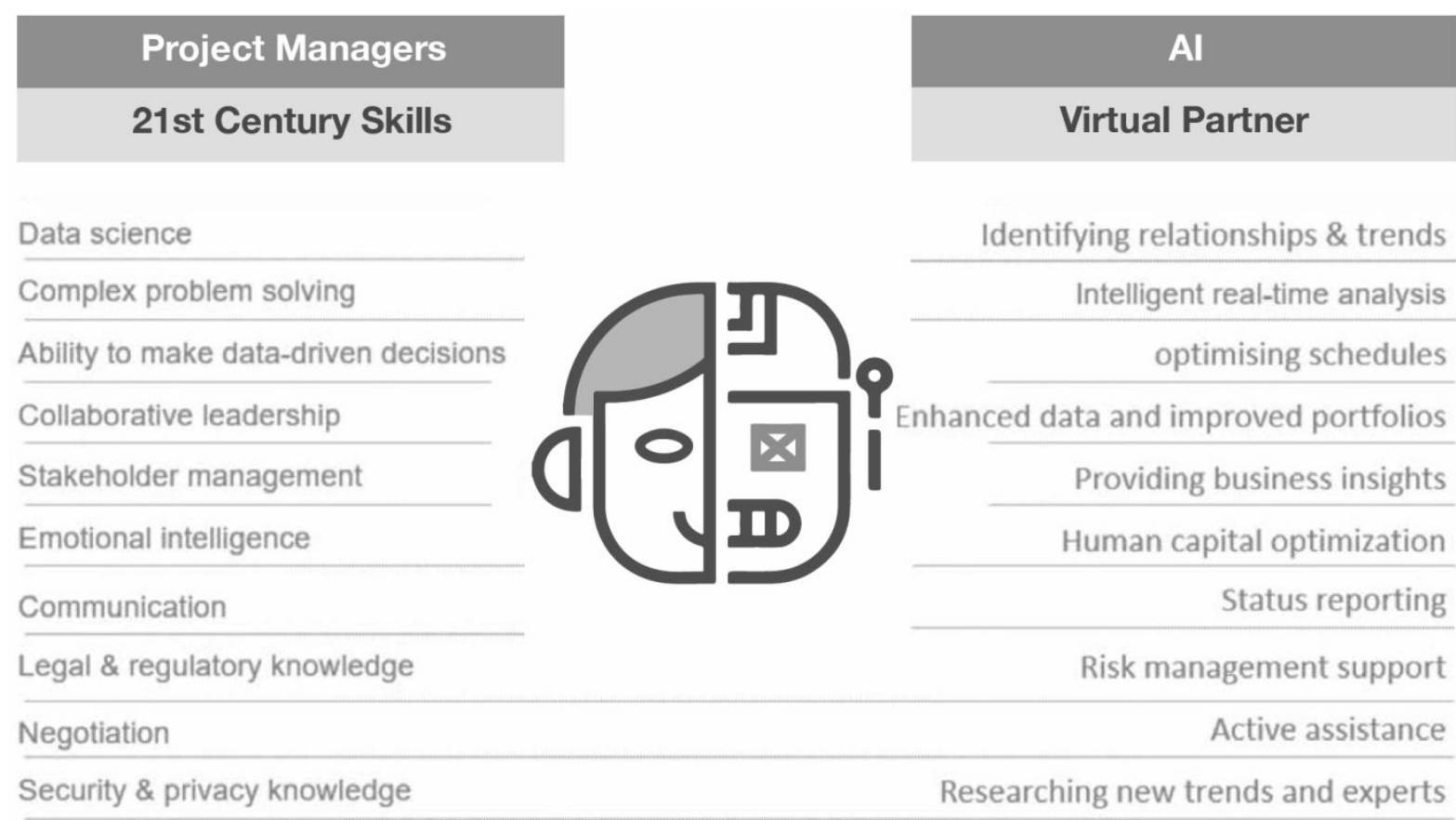

Fig 4.2 Source: A Virtual Partnership, PwC report 2019

While many of the daily tasks project managers perform can be automated through the use of AI, the true value behind Project Management Professionals lies in their ability to effectively mentor, guide, and communicate with other stakeholders. These are the higher-level skills where human interaction, sound and flexible judgment, empathy, and connection to teams and stakeholders need the "Human-ness" in order to be truly effective.

Robots and artificial intelligence may automate the tedious tasks that consume a small part of a project manager's time, such as taking information from multiple sources and putting together nice PowerPoint decks, focussing on proper messaging to the appropriate audience, and/or normalizing project data from incompatible systems. However, the most primary role of a project manager is leadership and communication.[6]

As discussed in the previous sections, the "humanness" aspect to project management is one thing that AI cannot seem to achieve currently. This means that the project manager role is here to stay or rather even expand into newer areas that will be discussed in this section. According to interviews with PMO directors and executive leaders for the 2018 PMI pulse of profession report, the following include possible roles the role of the PM is expanding to :

- Strategic Advisor: plans, executes, and delivers.

- Innovator: acts as product owner and developer;

- Communicator: is always clear and concise - no matter the audience;

- Big Thinker: is adaptable, flexible, and emotionally intelligent and

- Versatile Manager: has experience with all approaches-waterfall, Scrum, agile, lean, design thinking.

According to PMI's Job Growth and Talent Gap Report from 2018, by 2027, employers will need 87.7 million individuals working in project management-oriented roles, increasing the need for skilled and experienced project and program managers. Organizations will continue 
to place a greater focus on project management performance improvement to stay competitive and relevant. Champion organizations are already making greater investments in their talent through training, formal processes, defined career paths, and knowledge transfer project and program managers as seen in the figure below:

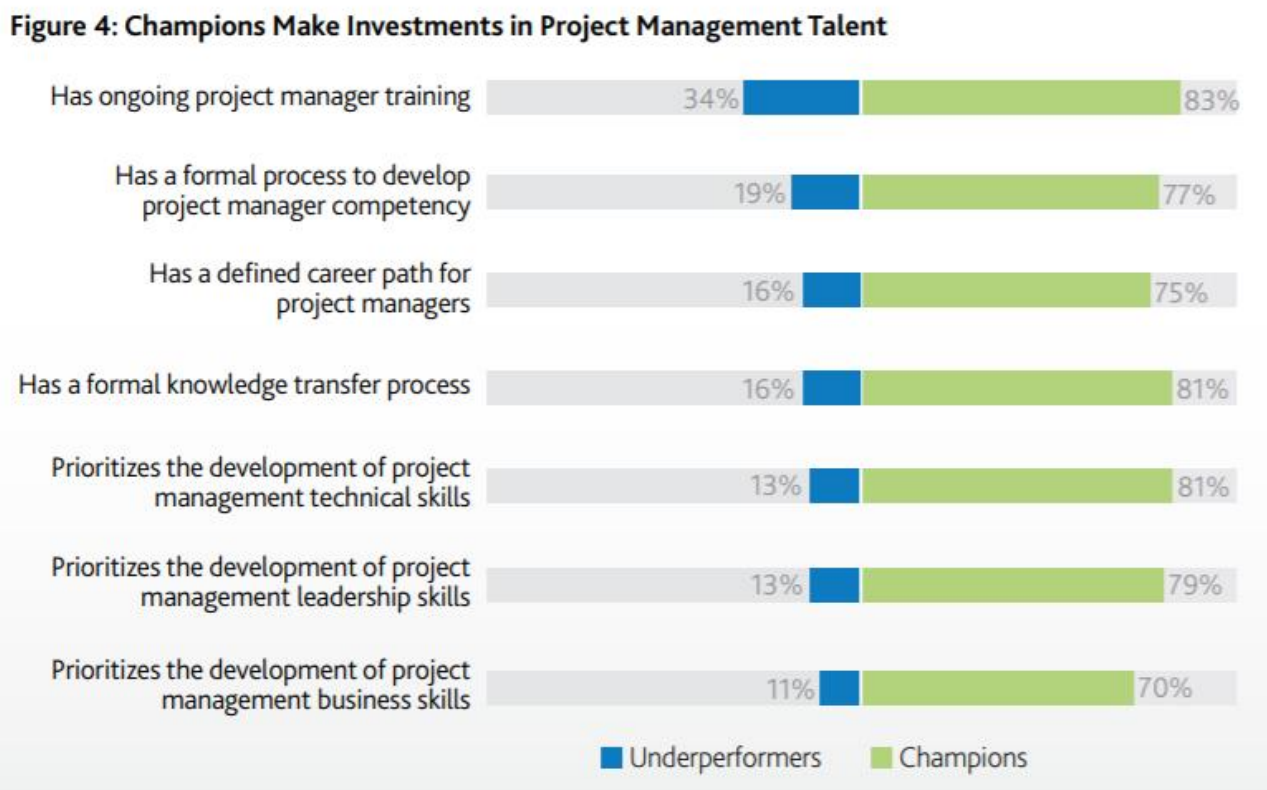

Fig 4.2.1 Source: PMI pulse of profession, 2018 [31]

\subsection{AI Tools and Techniques for the Project Manager role}

The Future of AI tools and techniques affecting the Project Manager role:

A PMI report[31] identified six AI technologies that are impacting organizations around the globe. The following three are currently impacting the largest number of businesses, it found that project managers predict that in the next three years, the impact of the following three AI technologies will grow:

\begin{tabular}{|c|l|}
\hline AI System Types & \multicolumn{1}{|c|}{ Description } \\
\hline Knowledge-based systems & $\begin{array}{l}\text { Understands the context of the data being processed, } \\
\text { helping support human learning and decision making. }\end{array}$ \\
\hline $\begin{array}{c}\text { Decision management } \\
\text { systems }\end{array}$ & $\begin{array}{l}\text { Creates an intelligent process or set of processes based on } \\
\text { rules and logic to automate decision making.[2] }\end{array}$ \\
\hline Expert systems & $\begin{array}{l}\text { Emulates and mimics human intelligence, skills or } \\
\text { behaviour in a particular field, topic or skill. Artificial } \\
\text { intelligence/expert systems (AI/ES) software can help } \\
\text { project managers capture their experiences of managing } \\
\text { projects so that they can share such experiences with } \\
\text { others. The software also offers the field the opportunity } \\
\text { to transmit key information such as PMIs Project } \\
\text { Management Body of Knowledge (PMBOK). }\end{array}$ \\
\hline
\end{tabular}




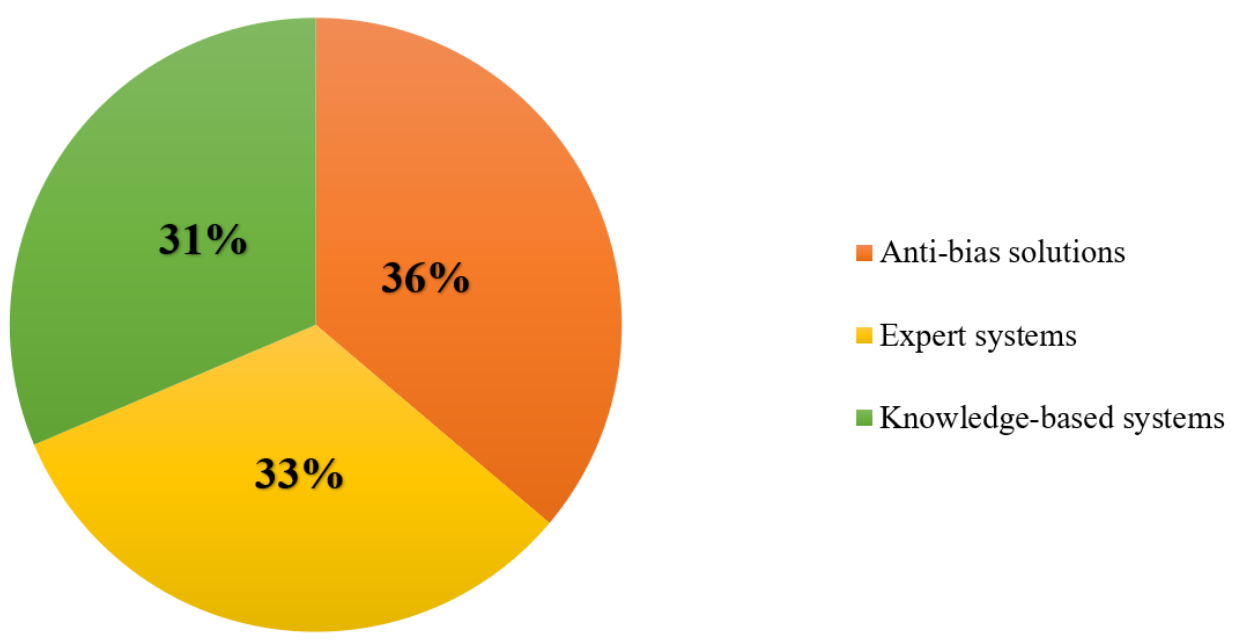

\section{The AI technologies most improving project managers' quality of work Vote $\%$}

Fig 4.3 Source: PMI's Pulse of the Profession survey [5]

\subsubsection{A future review on Project Managers}

Current project management tools and software can assist programme and project managers in optimising their efficacy and tracking key metrics against KPIs and project milestones. However, they cannot predict 'what if' and future scenarios or proactively alert project managers before a major issue arises. In addition, current tools provide information in 'pull' format and not 'push'.

According to PwC's Workforce of the Future Report, 2018, it is estimated that

- Demand is increasing for faster, more flexible, and easier-to-learn project management methodologies and approaches.

- The constantly-changing technical landscape - from social media, to web-based tools, to learning management systems-will present tremendous opportunities for exploration and experimentation.

- The shift toward on-demand, customized, and problem-specific learning with the use of AI will grow.

- Innovations in learning will continue to make it possible for the new worker to learn anything, anytime, and anywhere.

- In the increasingly complex project management environments that we see today, the need for such tools to proactively 'think' and 'do' on behalf of the project manager and provide on demand information to support their efficiency and effectiveness is clear.[31] 
AI will lead to the creation of more project management jobs

At least some or half of their job could be performed by a robot, algorithm, AI, device, or other technology

They're currently using some aspect of AI at work

Artificial intelligence (AI) will change their job in the next three years.

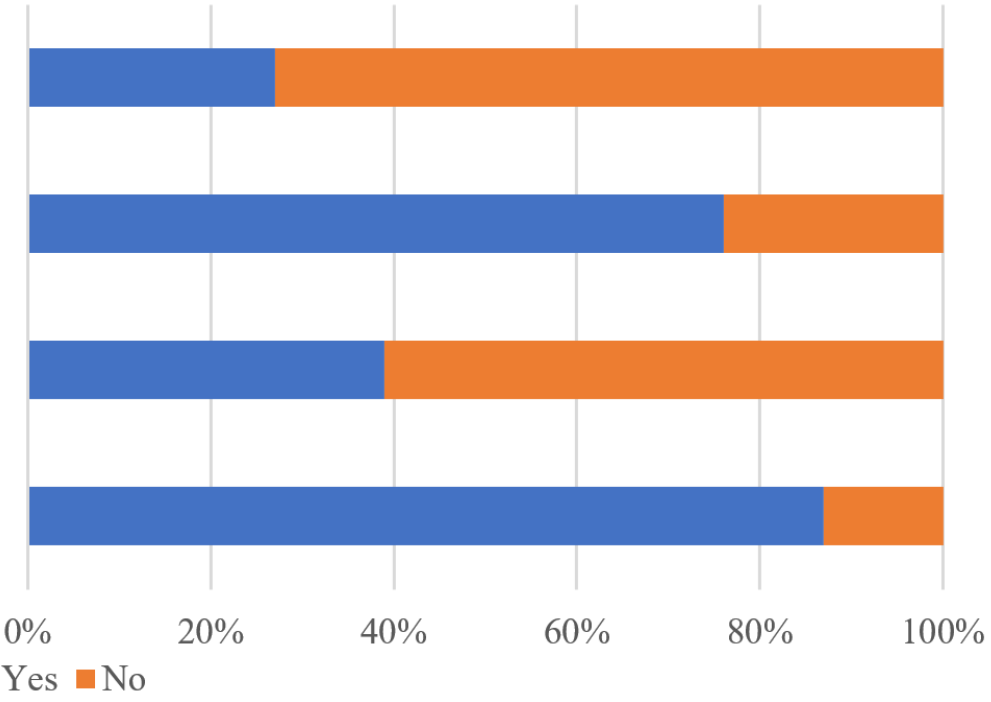

Fig 4.3.1 Source: Atlassian user review [2] \& PMI's Pulse of the Profession survey [5]

An organization's future lies not only in its portfolio of projects, but also in the hands of those who bring those projects - and the future - to life. With the right support from their organizations, project professionals can take these ideas and turn them into a reality by:

- Becoming leaders and true business partners in their organizations

- Asking the right questions

- Delivering the business benefits of the projects they manage.

\subsubsection{Building on Project Management Skills}

When it comes to responding and reacting in this environment, it's important for project managers to have more than just technical skills. They will be better equipped to sense change when they are well informed about an organization's strategic objectives and how their projects align.

According to research commissioned by APM and undertaken by PwC (a study of the contribution of project management and projects to the UK's economy and society - 'The Golden Thread'), the most important skills are leadership and management skills, budgeting and financial management, planning and monitoring, along with strategic management, digital skills and risk/opportunity management. All of these were rated as important by more than $80 \%$ of businesses.

Those who have leadership skills and strong business acumen-and deal well with ambiguity - can lead strategic initiatives that drive change within their organizations. Improving Delivery practices will be a key tool in the project manager's toolbox as well.

It's important for project managers to understand and be part of the technological trends that are going to have the largest influence on demand for project work so that they can participate in VALUE CREATION since PM's value goes beyond the functional aspect of project management.[31] 


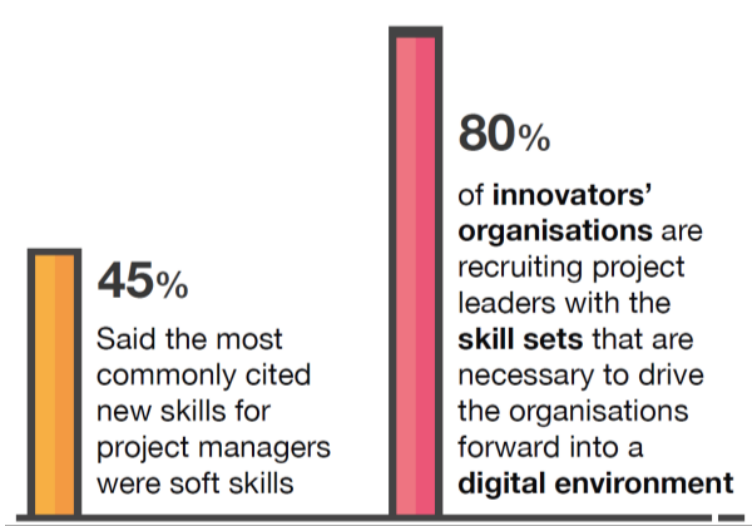

Fig 4.3.2 Source: PMI’s A Virtual Partnership Report, 2019

Organizations will continue to place emphasis on developing project leaders and upskilling them so that they add value to their organizations and see through to the digital transformation phase.

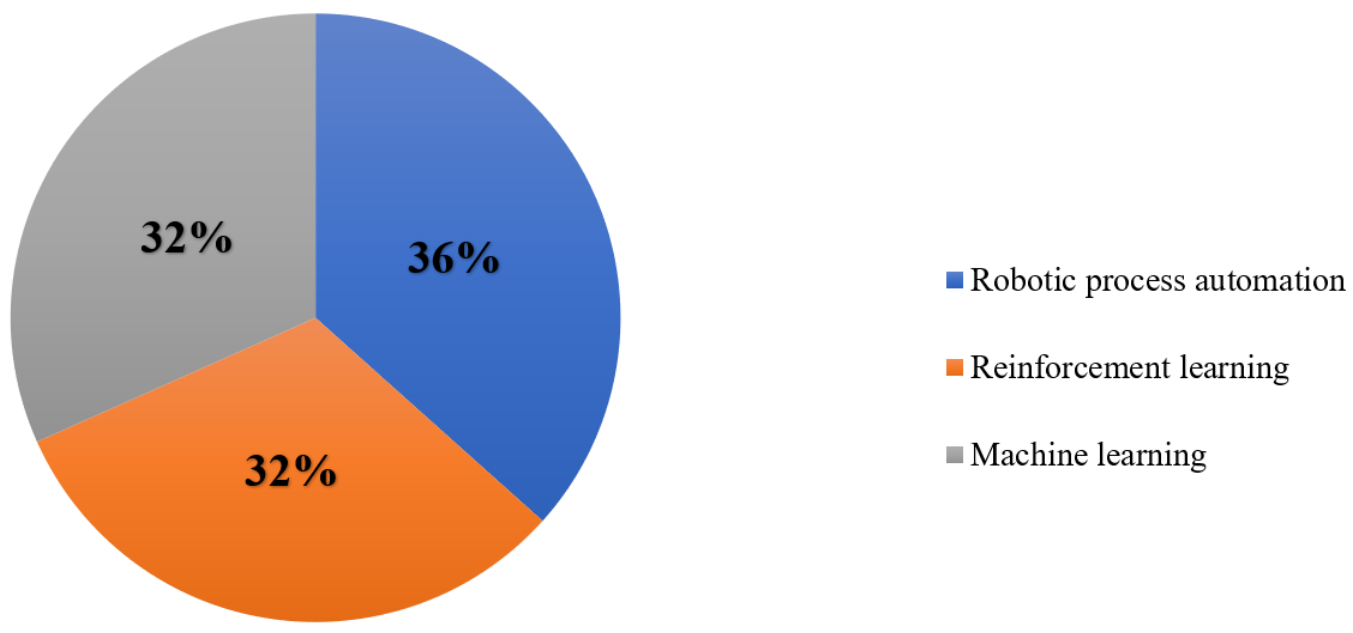

The top technologies project managers said are boosting project management productivity Vote $\%$

Fig 4.3.3 Source: PMI's Pulse of the Profession survey [5]

As previously discussed in Chapter 3, tools and technologies such as RPA, Reinforcement learning and Machine Learning are the future of AI in project management. The above graph represents the technologies that project managers use to help boost project management productivity.

\subsection{Predictive Analytics}

According to IBM experts, Predictive analytics is the use of advanced analytic techniques that leverage historical data to uncover real-time insights and to predict future events. The use of predictive analytics is a key milestone on your analytics journey - a point of confluence where classical statistical analysis meets the new world of artificial intelligence (AI). [36]

According to PMI's Pulse of Profession 2018 report, most "Champions"(Organizations with $80 \%$ or more of projects being completed on time, on budget, meeting business intent, and having high benefits realization maturity) in the industry 
use Predictive Analytics for their projects such that their goals can be met, delivered on time and within budget.

\begin{tabular}{|c|c|}
\hline Best Suited for Them & Champions \\
\hline Average percentage of projects using predictive approaches & $44 \%$ \\
\hline Average percentage of projects using agile approaches & $30 \%$ \\
\hline Average percentage of projects using hybrid approaches & $23 \%$ \\
\hline Average percentage of projects using "other" approaches & $4 \%$ \\
\hline
\end{tabular}

Fig 4.4 Source: PMI Pulse of Profession, 2018

Today's unprecedented combination of intuitive tools, new predictive techniques and hybrid cloud deployment models makes predictive analytics and modelling accessible. Organizations now have the power to extract value from previously unexplored "dark data"- including everything from raw text to geolocational information.[36]. Project management is no exception and a variety of machine learning algorithms are applied specifically to anticipate cost overruns, forecast resource needs, and make time tracking effortless.

\subsubsection{How does Predictive Analytics help Project Managers?}

Project managers work in swamps of data - tasks, time estimates, priorities, milestones, capacity, workload, costs, and other digitized variables. Data is valuable only if it's broken down, analyzed, and refined. A possible way to unlock the value of project data is to apply a predictive model to it.

- Predictive Analytics helps project managers analyze their projects under various scenarios and create simulations out of their programs and portfolios.

- It helps project managers answer a vast range of "what-if" questions that predict the possible outcome of the project if something has to be changed.

- Predictive Analytics that powers project forecasting software will instantly help them investigate the chain reaction and make decisions backed up by data when project management is under concern.[34] 


\section{Future of Project Management Office}

As the core of the PMOs functions is data-intensive, it is inevitable that adoption of artificial intelligence - with its much higher capabilities in handling and processing data than humans will bring about some major disruptions.

\subsection{PMO roles and functions, and the impacts of $\mathrm{AI}$}

Desouza and Evaristo [44] classify PMOs in two dimensions: administrative and knowledge-intensive; they also segment the roles of PMOs into three levels: strategic, tactical, and operational, each with differing functions (see table 5.1).

\begin{tabular}{|l|c|c|c|}
\hline \multicolumn{1}{|c|}{\begin{tabular}{c}
\multicolumn{1}{c|}{$\begin{array}{c}\text { FUNCTION / } \\
\text { PMO TYPE }\end{array}$} \\
\cline { 2 - 4 }
\end{tabular}} & $\begin{array}{c}\text { Supporting } \\
\text { (operational Level) }\end{array}$ & $\begin{array}{c}\text { Controlling } \\
\text { (tactical level) }\end{array}$ & $\begin{array}{c}\text { Directing } \\
\text { (strategic } \\
\text { level) }\end{array}$ \\
\hline $\begin{array}{l}\text { Monitoring, Reporting \& } \\
\text { Communications }\end{array}$ & $\mathrm{X}$ & $\mathrm{X}$ & $\mathrm{X}$ \\
\hline $\begin{array}{l}\text { Knowledge Integration \& } \\
\text { Information Repositing }\end{array}$ & $\mathrm{X}$ & $\mathrm{X}$ & $\mathrm{X}$ \\
\hline $\begin{array}{l}\text { Project Evaluation Process } \\
\text { (reviews, change requests) }\end{array}$ & $\mathrm{X}$ & $\mathrm{X}$ & $\mathrm{X}$ \\
\hline Multi Project Coordination & & $\mathrm{X}$ & $\mathrm{X}$ \\
\hline Portfolio Oversight & & $\mathrm{X}$ & $\mathrm{X}$ \\
\hline Compliance Management & & $\mathrm{X}$ \\
\hline HR Responsibilities & & & $\mathrm{X}$ \\
\hline $\begin{array}{l}\text { Strategic Management } \\
\text { (organisational change } \\
\text { management) }\end{array}$ & & & \\
\hline $\begin{array}{l}\text { Organisational Knowledge } \\
\text { Management (capture, sharing, }\end{array}$ & & & \\
\hline
\end{tabular}

1. Administrative PMO: serves a primarily administrative function, and is not directly responsible for project success. It is a passive PMO, providing services only on request.

These functions can mostly be replaced by AI. As detailed in this report, AI has been shown to be effective in performing mundane administrative tasks, more effectively and efficiently, and less error-prone than humans. "As organizations aggressively 
pursue digitalization, and projects become more complex, future success for the PMO will depend on the contribution and participation of many people across the organization. A PMO that is fixated solely on control - and a consistent, one-size-fitsall process - is already viewed as a barrier to progress by many enterprises. In 2030, it will have no place." [45]

2. Knowledge-intensive PMOs: are the central point of accountability for the successful delivery of specific projects. They take an active role in managing best practices of project management, learning from projects (both failures and successes), and improving the maturity of project management at the organization.

a. The functions of the tactical PMO cannot be outrightly replaced by AI systems, as they require a lot of the human element which machines simply cannot possess.

They can, however, be supported by AI, and stand to gain the benefits of being freed from performing mundane tasks, thus, having more time to spend on the valuable ones.

b. Strategic level PMOs ensure projects are aligned with strategic objectives of the organization. These functions will remain largely undisturbed by AI in the foreseeable future, as these require purely human competencies that machines cannot replicate.

While AI can provide information to promote better decision making, it can neither assimilate this information nor make these strategic decisions.

\subsection{Outlook For PMOs}

As smart machines increasingly assume and absorb aspects of work - and not only do what was previously reserved for humans but also what was thought to be impossible for machines - the differentiating value of human beings will live in applying creativity, critical thinking, empathy and innovation to new outcomes. With organizations demanding increasing value, PMOs will need to focus more and more on strategy, innovation, agility, and stakeholder engagement.

Gartner [45] projects the following for PMOs:

1. Much of the "work" of today's project management office (PMO) will be eliminated as artificial intelligence (AI) takes on traditional project management (PM) functions, and reporting/supportive PMOs will disappear.

2. By 2030, the multitude of PMOs existing in organizations will have to amalgamate into one function concerned with change, strategy, product evolution and organizational governance.

3. Most of today's PMOs are part of IT, and many Enterprise PMOs (EPMOs) are part of a business unit. In the digital world, these distinctions will blur and become unimportant.

4. PMOs failing to adapt will be dissolved because no company will need processheavy, risk-averse compliance administrators. 


\begin{tabular}{|c|c|c|c|}
\hline $\begin{array}{c}\text { PM } \\
\text { Activity } \\
\text { Impacted }\end{array}$ & $\begin{array}{c}\text { Sector or area } \\
\text { of PM }\end{array}$ & Comment & Horizon \\
\hline $\begin{array}{c}\text { Supporting } \\
\text { PMO }\end{array}$ & $\begin{array}{c}\text { Administrative } \\
\text { project support }\end{array}$ & $\begin{array}{c}\text { Virtually all activities } \\
\text { to be replaced by AI }\end{array}$ & 5-10 years \\
\hline $\begin{array}{c}\text { Controlling } \\
\text { PMO }\end{array}$ & $\begin{array}{c}\text { project support } \\
\text { Administrative } \\
\text { compliance } \\
\text { control }\end{array}$ & $\begin{array}{c}\text { Activities to be largely } \\
\text { complemented by AI }\end{array}$ & 5-10 years \\
\hline $\begin{array}{c}\text { Directing } \\
\text { PMO }\end{array}$ & $\begin{array}{c}\text { Strategic project } \\
\& \text { portfolio } \\
\text { management }\end{array}$ & $\begin{array}{c}\text { Will remain largely } \\
\text { unaffected by AI, } \\
\text { barring AI-assisted } \\
\text { insights to inform } \\
\text { decision making }\end{array}$ & $\begin{array}{c}\text { Not in the foreseable } \\
\text { future) }\end{array}$ \\
\hline
\end{tabular}

Table 5.2: Summary of AI impacts on PMO (all entries in this table are from a highly reliable source: Gartner [45]) 


\section{CODA}

As the name suggests this chapter is the culmination and amalgamation of our findings. We attempt to decipher the maze of interconnections and interrelationships between different disciplines and affected stakeholders. Let's start by detailing our approach, and then implementing it to see where the reasoning might lead us.

\subsection{Approach / Methodology}

The issues involved in the way in which artificial intelligence will impact the worlds of projects and project management are so complex that it seemed to us that a good way of displaying the complexity could be through the controversy actor network approach which we learned about earlier in the MoTIS year. [55] [56]

We will begin this controversy approach by presenting the main controversies we have identified, then we will select one of them to apply the principle and the protocol on in order to make it clear to the reader. This will include explaining the controversy, identifying what is at stake, listing the key players involved (advocates and opponents), presenting their corresponding arguments, showing how the controversy might evolve over time through a series of phases, and finally presenting a two-dimensional map showing the various positions of these players.

\subsection{Implementation}

\subsubsection{Main Controversies}

Through the work we have done during the course of writing this report, we have identified at least four controversies which we will list below.

1. AI will lead to a revolution (not just an evolution) in Project Management.

a. AI will replace Project Management related organisational configurations (functions and routines currently used to manage projects).

b. AI will render current Project Management standards and methodologies obsolete.

c. AI will replace the project manager.

2. Project-based thought will vanish in 10 years.

In order to elucidate, we select one amongst the controversies identified and try to draw out the actors and their arguments. The controversy which we focus on is "AI will replace Project Management related organisational configurations".

\subsection{Programme | Anti-Programme Analysis}

In this section, we will discuss some of the elements/actors pushing for and against a radical replacement of project management by AI as quickly as possible from a "Programme $\mid$ AntiProgramme" perspective.

We will do this by introducing the human and non-human actors first, then visualizing their involvement in the present and future steps of AI development adapted from (Scott Middleton, 3 ways AI will change project management for the better, 2017 [2]). 


\subsubsection{Actors "for" change}

\begin{tabular}{|c|c|c|}
\hline Actor & Role & Reason why in favor \\
\hline $\begin{array}{l}\text { AI type } \\
\text { Management } \\
\text { consultants }\end{array}$ & $\begin{array}{l}\text { Introduce and implement AI } \\
\text { systems to project } \\
\text { management. }\end{array}$ & $\begin{array}{l}\text { New prospects and opportunities in the } \\
\text { PM consultant field through increased } \\
\text { demand. }\end{array}$ \\
\hline $\begin{array}{l}\text { Business } \\
\text { sponsors }\end{array}$ & $\begin{array}{l}\text { Ownership of projects and } \\
\text { authority to make financial } \\
\text { decisions. }\end{array}$ & $\begin{array}{l}\text { Cheaper and more productive project } \\
\text { management along with more efficient } \\
\text { documentation and progress reporting. }\end{array}$ \\
\hline $\begin{array}{l}\text { Solution } \\
\text { development } \\
\text { teams }\end{array}$ & $\begin{array}{l}\text { Teams allocated to work on } \\
\text { projects full-time and report to } \\
\text { a team leader/project manager. }\end{array}$ & $\begin{array}{l}\text { More productivity and efficiency through } \\
\text { AI assistance and AI-powered PM tools. } \\
\text { easily accessible data and automated } \\
\text { analysis and progress reporting. }\end{array}$ \\
\hline $\begin{array}{l}\text { Agile } \\
\text { practitioners }\end{array}$ & $\begin{array}{l}\text { PMs who use the Agile } \\
\text { iterative approach to managing } \\
\text { software development projects } \\
\text { that focuses on continuous } \\
\text { releases and customer } \\
\text { feedback. }\end{array}$ & $\begin{array}{l}\text { More productivity and efficiency through } \\
\text { AI assistance and AI-powered PM tools. } \\
\text { easily accessible data and automated } \\
\text { analysis and progress reporting. }\end{array}$ \\
\hline $\begin{array}{l}\text { Budget (non- } \\
\text { human) }\end{array}$ & $\begin{array}{l}\text { The amount of funds allocated } \\
\text { for a certain project which } \\
\text { usually limit spending to } \\
\text { within certain criteria }\end{array}$ & $\begin{array}{l}\text { Cheaper realization of project objectives } \\
\text { through less human manpower or more } \\
\text { productivity of the solution development } \\
\text { team with less working hours. }\end{array}$ \\
\hline Researchers & $\begin{array}{l}\text { Academic researchers who } \\
\text { develop AI solutions for } \\
\text { project management. }\end{array}$ & $\begin{array}{l}\text { New opportunities and more funding } \\
\text { relocated towards research on new AI } \\
\text { technologies that could be integrated in } \\
\text { project management. }\end{array}$ \\
\hline $\begin{array}{l}\text { AI-based } \\
\text { enterprise } \\
\text { software } \\
\text { system } \\
\text { (non-human) }\end{array}$ & $\begin{array}{l}\text { To replace the entire existing } \\
\text { enterprise software systems }\end{array}$ & $\begin{array}{l}\text { The old system will soon be obsolete in } \\
\text { an AI world. }\end{array}$ \\
\hline $\begin{array}{l}\text { AI-based } \\
\text { enterprise } \\
\text { project } \\
\text { management } \\
\text { system } \\
\text { (non-human) }\end{array}$ & $\begin{array}{l}\text { To enable some or all projects } \\
\text { to be managed using AI } \\
\text { project management systems } \\
\text { which can be built up from } \\
\text { modules. }\end{array}$ & $\begin{array}{l}\text { Enables projects to be completed more } \\
\text { successfully. }\end{array}$ \\
\hline $\begin{array}{l}\text { AI-based } \\
\text { autonomous } \\
\text { project related } \\
\text { systems } \\
\text { (non-human) }\end{array}$ & $\begin{array}{l}\text { To enable current PM } \\
\text { practitioners to benefit from } \\
\text { and try out AI based systems } \\
\text { without upsetting existing PM } \\
\text { processes too much.. }\end{array}$ & $\begin{array}{l}\text { Enables AI PM solutions to be introduced } \\
\text { gradually. }\end{array}$ \\
\hline
\end{tabular}




\subsubsection{Actors "against" change}

\begin{tabular}{|l|l|l|}
\hline \multicolumn{1}{|c|}{ Actor } & \multicolumn{1}{|c|}{ Role } & \multicolumn{1}{c|}{ Reason why against } \\
\hline $\begin{array}{l}\text { Pre AI type } \\
\text { IS consultants }\end{array}$ & $\begin{array}{l}\text { they are the allies of the company and } \\
\text { also provide PM labour }\end{array}$ & $\begin{array}{l}\text { The old way is good. Anyway } \\
\text { we can adapt to include AI. } \\
\text { We've been partners for 20 } \\
\text { years. You know and trust us. }\end{array}$ \\
\hline $\begin{array}{l}\text { Assistant project } \\
\text { managers }\end{array}$ & $\begin{array}{l}\text { Apprentice or junior project managers } \\
\text { that are mainly responsible for aiding } \\
\text { the project manager on his duties. }\end{array}$ & $\begin{array}{l}\text { Elimination of the need for most } \\
\text { human involvement in } \\
\text { organisational tasks and personal } \\
\text { assistance for the PM. }\end{array}$ \\
\hline $\begin{array}{l}\text { Worker Unions } \\
\text { Prospective } \\
\text { project managers }\end{array}$ & $\begin{array}{l}\text { An association of workers forming a } \\
\text { legal unit which acts as bargaining } \\
\text { agent and legal representative for the } \\
\text { employees that were affected. }\end{array}$ & $\begin{array}{l}\text { Various jobs in the PM field } \\
\text { would be eliminated or replaced } \\
\text { with the involvement of more } \\
\text { efficient AI systems. } \\
\text { or managers with entry level }\end{array}$ \\
\hline $\begin{array}{l}\text { Traditional IT } \\
\text { and IS } \\
\text { companies }\end{array}$ & $\begin{array}{l}\text { Companies relying on traditional } \\
\text { project management methods that are newly graduated } \\
\text { tend to be resistant to change. }\end{array}$ & $\begin{array}{l}\text { As a result of more efficient AI } \\
\text { systems' involvement in the PM } \\
\text { field, more specialized } \\
\text { background is required of PMs } \\
\text { and less opportunities for rookie } \\
\text { PMs are predicted to be } \\
\text { available. }\end{array}$ \\
\hline $\begin{array}{l}\text { Competition will become more } \\
\text { intense with the increased } \\
\text { productivity and analytical } \\
\text { efficiency, and changing the PM } \\
\text { approach might be costly and } \\
\text { time-consuming. }\end{array}$ \\
\hline
\end{tabular}




\subsubsection{Socio Technical diagram}

This Programme | Anti-Programme visual representation will use the actors mentioned above in section 6.3, as well as the different AI-PM integration phases according to Scott Middleton, founder and CEO of stratejos' article (3 ways AI will change project management for the better, 2017 [2]) mentioned in section 3.2 of this report.

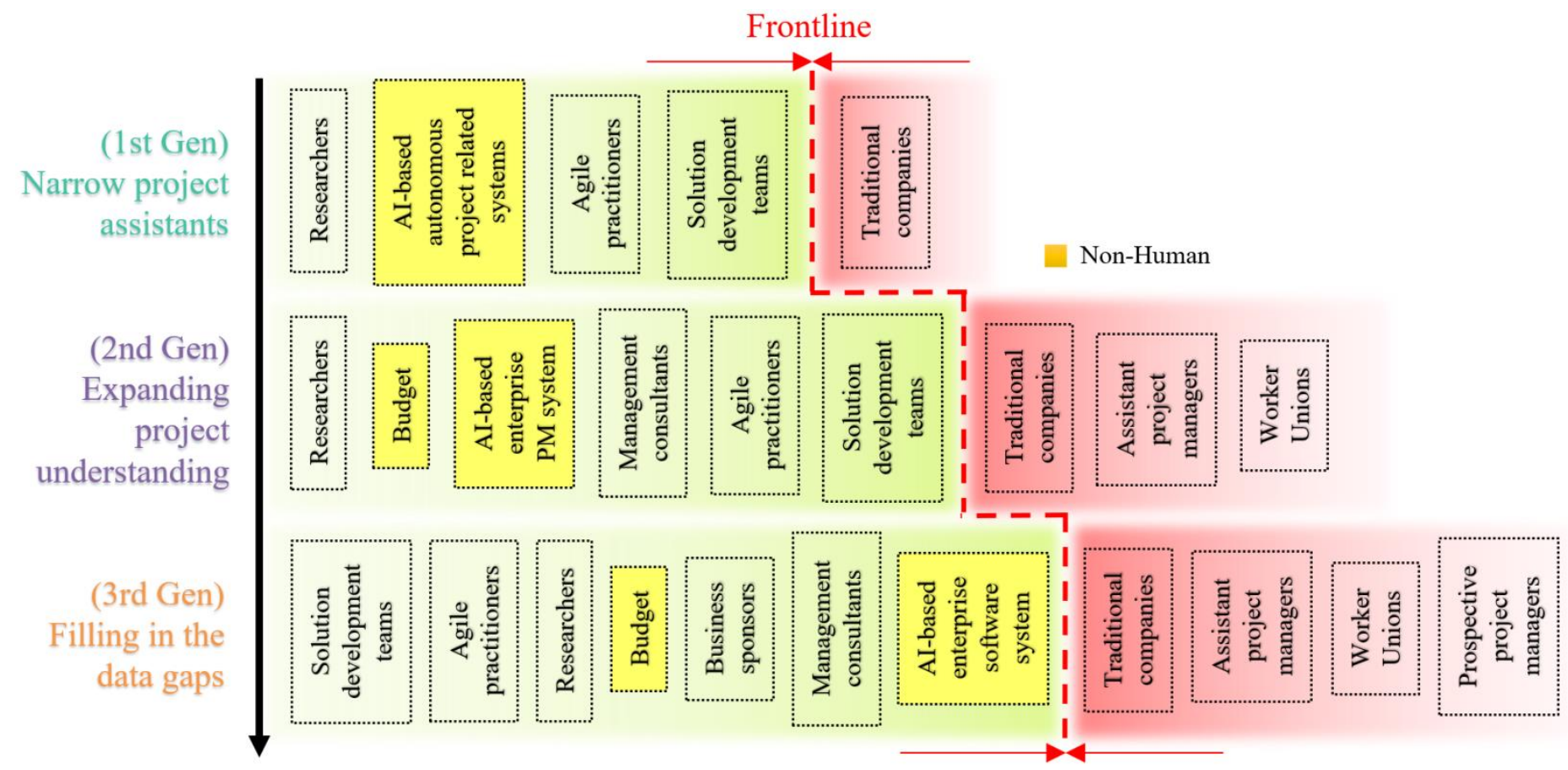

\subsection{Arguments for and against}

This section aims at showing the arguments for and against the use of AI in project management, as well as the actors making them.

\subsubsection{Arguments "for"}

\begin{tabular}{|l|c|}
\hline \multicolumn{1}{|c|}{ Argument } & Actor \\
\hline $\begin{array}{l}\text { AI enables project management to provide more insights into possible } \\
\text { outcomes, which will enhance the quality of decision-making. By } \\
\text { finding relationships and trends in data, the system will remove not } \\
\text { necessary information leaving management to focus on the most } \\
\text { important information. }\end{array}$ & $\begin{array}{l}\text { Management } \\
\text { consultants }\end{array}$ \\
\hline
\end{tabular}




\begin{tabular}{|l|l|}
\hline $\begin{array}{l}\text { AI transforms project management by changing the way human } \\
\text { resources are managed. AI can enhance Human Capital Optimization (a } \\
\text { new form of HRMS) by calculating the best allocation of resources, } \\
\text { Identifying the right skill for the right job, Pinpointing training needed } \\
\text { for a specific employee, Predicting resources excess or shortage, } \\
\text { Providing feedback about the project manager's behaviour and } \\
\text { competency. This could be a solution to project failure which is mostly } \\
\text { caused by teams incapable of fully grasping a project's main goals and } \\
\text { objectives. }\end{array}$ & $\begin{array}{l}\text { Solution } \\
\text { development } \\
\text { teams }\end{array}$ \\
$\begin{array}{l}\text { Budget (Non- } \\
\text { Human) } \\
\text { Business sponsors }\end{array}$ \\
$\begin{array}{l}\text { Applying AI will assist the project managers by performing } \\
\text { administrative and repetitive tasks on their behalf, therefore augmenting } \\
\text { their skills. }\end{array}$ \\
$\begin{array}{l}\text { Unlike traditional project management tools, AI can predict more } \\
\text { accurately future issues based on previous data. This includes risks } \\
\text { related to people, vendors, entities etc on the project. Cost assumptions } \\
\text { and time constraints can be examined by combining current project data } \\
\text { with historic data to run multiple scenarios and generate, assess and } \\
\text { rank viable outcomes. }\end{array}$
\end{tabular}

\subsubsection{Arguments "against"}

\begin{tabular}{|l|c|}
\hline \multicolumn{1}{|c|}{ Argument } & Actor \\
\hline $\begin{array}{l}\text { AI cannot appropriately distinguish between approved and restricted } \\
\text { data and violates the right to privacy. This can promote collecting } \\
\text { personal data, unauthorised recordings and making unethical decisions. }\end{array}$ & $\bullet \begin{array}{l}\text { Traditional IT and } \\
\text { IS companies }\end{array}$ \\
\hline $\begin{array}{l}\text { Incomplete and missing data reflects the statistical power of a } \\
\text { prediction and produces estimates leading to invalid conclusions. } \\
\text { Managing a set of stakeholders and various unpredictable events, AI- } \\
\text { led projects will mostly fail to react appropriately to these challenges. }\end{array}$ & $\begin{array}{l}\text { Pre AI type } \\
\text { consultants }\end{array}$ \\
\hline $\begin{array}{l}\text { Repetitive and low skilled jobs might no longer be available. } \\
\text { is }\end{array}$ & $\begin{array}{l}\text { Worker Unions } \\
\text { Prospective } \\
\text { project managers } \\
\text { Assistant project } \\
\text { managers }\end{array}$ \\
\hline $\begin{array}{l}\text { Lack of explainability of AI causes distrust. Most AI powered softwares } \\
\text { and tools that exist as of today are blackbox AI and not explainable, i.e. } \\
\text { the decisions and results they produce cannot be easily understood or } \\
\text { justified. One cannot trust a machine's product blindly. }\end{array}$ & $\bullet \begin{array}{l}\text { Traditional IT and } \\
\text { IS companies }\end{array}$ \\
\hline
\end{tabular}




\subsection{Author's Opinions}

We'd like to conclude this section of the report by giving our relevant opinions on the controversy.

\subsubsection{Benjamin}

Having examined the controversy, I believe that AI will lead to more of an evolution than a revolution in project management. Here is what I mean by that assertion, more precisely:

1. It is irrefutable that none of the phases and processes of the PMBOK - which is presently the prevalent standard for managing projects - is immune to infiltration by AI, albeit some being more susceptible than others. However, it is not so much that the phases and/or processes will be replaced, but more so that the way they are performed in practice will change in some ways - particularly as it pertains to the tools and techniques used to achieve their respective goals.

2. Organisational configurations (functions and routines currently used to manage projects), suggest that while AI will undoubtedly take over a lot of these functions, the fundamental core remains - certainly over the next 10 years, at least. The PMO for instance, I believe will maintain its place in organisations, albeit with the prerequisite that it must evolve in the type of value it provides - mutate into an entity capable of managing organisational change, strategy, and governance through increased innovation, agility, and stakeholder engagement.

\subsubsection{Charul}

In my opinion, human civilization has defined itself through its ability to produce equipment, tools and machines that make our lives easier and allow us to achieve increasingly great things. I have learned that AI creates the possibility of automated processes and intelligent tools that will reduce manual work but it will require a certain amount of project management maturity. We can see great opportunities for implementing AI-based project systems in large project organizations as a way of facilitating predictive steering of complex transformation projects and thus boosting project success.

The future of project management will be heavily influenced by technological breakthroughs, and there is no doubt that AI will change the course of how project management tasks are delivered and controlled in the future. But it is important to remember that there is something AI cannot do - be human. This means that project managers will also stay relevant in the age of AI if they focus on the core skills of project management and progressively move into work that emphasizes human skills.

\subsubsection{Daniel}

After an in-depth analysis of the impact of AI on Project management, I observed that $\mathrm{AI}$ is growing technology that is affecting our lives in every aspect. Project management as a technique will need to be supported in order to evolve. Evolution comes with changes, methodologies, processes, teams/employees, tools will have to adapt to AI. Such changes will lead to the creation of individuals with AI oriented skills in order to manage, merge the technology to today's project management techniques.

\subsubsection{Neha}

AI requires a PM's input and insights to perform its best whilst a PM's value within the organization increases with AI aiding and assisting them in automatable tasks. This value 
is created when AI offers the required tools to allow a PM to focus on providing better team guidance, leadership and provide better value to stakeholders.

AI, as attractive as it may be, still needs to be monitored and cannot always be trusted. This issue around trust, I figure, is due to the lack of human feel but also due to AI having problems of bias and explainability. Not all AI is explainable i.e. decisions made by AI aren't always justifiable or understandable. This sense of trust that has to be developed between a client and a project manager is crucial to the success of projects and simply cannot be achieved by AI.

\subsubsection{Urmila}

I consider that AI-driven technologies will transform enterprise systems into nextgeneration intelligence platforms that augment human skills and foster new ways of humanmachine interactions. Technological advancements and landmark breakthroughs in natural language processing, machine learning, are going to become the building blocks of AIpowered management experiences which will impact how the large organizations will view strategy and their internal configurations. Such organizations should be prepared for massive disruptions in their methodologies and approaches to project management.

This involves a change of culture and mindset of its employees. It implies that they will need new skills to interact successfully with AI. As this disruption will be the norm in the coming years they will need to revamp or revisit the existing processes. It means that organizations need to ensure a greater degree of flexibility in their processes; which in other words means that organizational Agility will have to increase manifold.

As a way to increase their agility, and to comprehensively adapt to the market cycles also (because not just the nature of management will change, but also the nature of projects as well), I think that there will be a tug of war between the currently established PMI standards and the new models which are currently under development. I am not certain whether PMI will/can win this battle. 


\section{CONCLUSION}

For further work, we would like to recommend the following 5 directions:

1. Identify and characterize the emerging firms which are positioning themselves as consultants to big companies and proposing AI process solutions.

2. Investigate how GAFAM and Tesla companies are using AI for their projects. They are the forerunners.

3. Do a survey on the topic with MoTIS alumni.

4. Interview selected MoTIS and ESIEE alumni (Turing prize winner Yann LeCun who directs the FB AI lab)

5. Investigate how the PM organisations like PMI and IPMA and even ISO are preparing for change.

When we started researching and working on the report we did not expect to find that the topic of AI \& PM was so mature and that so many AI solutions were already finding their way into PM processes. Nor that large consultancies like Gartner, Accenture, PWC were taking it so seriously. The client was right to request a study such as ours. Companies, existing and future project management practitioners should already be raising their awareness of how AI will impact their future working environment.

Our findings are rather modest. We have tried to highlight significant information from the most interesting studies and reports we encountered. Also to map out how the worlds of AI and PM will intersect and to show which PM processes will be affected earliest and which ones will be difficult to automate. Clearly there will be disruptions which will require considerable change management and coaching for individuals and organizations. Indeed this could be a future profession!

For further reading we recommend the:

1. PWC report

2. https://research.aimultiple.com/ai-consulting/ 


\section{GLOSSARY}

\begin{tabular}{|c|c|}
\hline $\begin{array}{l}\text { TERM / } \\
\text { ABBREVIATION }\end{array}$ & DEFINITION \\
\hline AI & $\begin{array}{l}\text { AI can be defined as a machine that inputs (data) from the real world, } \\
\text { processes that input and makes specific decisions as a result to } \\
\text { achieve a goal }\end{array}$ \\
\hline Adaptive Boosting & $\begin{array}{l}\text { The main difference with Bootstrap aggregating neural networks is } \\
\text { that adaptive boosting neural networks use weights that are readjusted } \\
\text { on every iteration giving less importance to those solutions that have } \\
\text { not been classified correctly. As a result, classifiers focus on more } \\
\text { complex samples obtaining a faster solution each time. }\end{array}$ \\
\hline AGI & $\begin{array}{l}\text { AGI can be considered as the Human-Level AI, AGI is the type of AI } \\
\text { which can mimic humans at almost all levels. Theoretically, AGI can } \\
\text { perform all types of tasks that humans do and even some tasks that } \\
\text { are hard for humans to accomplish. }\end{array}$ \\
\hline Autonomous Systems & $\begin{array}{l}\text { Autonomous systems are physical and virtual software and hardware } \\
\text { systems that are able to accomplish a task, reach a goal, interact with } \\
\text { their surroundings, and achieve an objective with minimal human } \\
\text { involvement. The goal of autonomous systems is to streamline things } \\
\text { with as little human interaction as possible. }\end{array}$ \\
\hline Bayesian Model & $\begin{array}{l}\text { A Bayesian model is a statistical model where you use probability to } \\
\text { represent all uncertainty within the model, both the uncertainty } \\
\text { regarding the output but also the uncertainty regarding the input (aka } \\
\text { parameters) to the model. }\end{array}$ \\
\hline Bootstrap Aggregation & $\begin{array}{l}\text { Bootstrap aggregating neural networks are a combination of multiple } \\
\text { artificial neural network classifiers. They use more than one classifier } \\
\text { based on ANNs so the final decision is taken from each classifier by a } \\
\text { voting system. }\end{array}$ \\
\hline $\begin{array}{l}\text { Conversational/Human } \\
\text { Interactions }\end{array}$ & $\begin{array}{l}\text { This is defined as machines and humans interacting with each other } \\
\text { through conversational forms of interaction and content across a } \\
\text { variety of methods including voice, text, and image forms. This } \\
\text { includes machine to human, human to machine, and back and forth } \\
\text { human and machine interaction. The objective of this pattern is } \\
\text { enabling machines to interact with humans how humans interact with } \\
\text { each other. }\end{array}$ \\
\hline CRISP-DM & $\begin{array}{l}\text { Cross-industry standard process for data mining, known as CRISP- } \\
\text { DM, is an open standard process model that describes common } \\
\text { approaches used by data mining experts. It is the most widely-used } \\
\text { analytics model. }\end{array}$ \\
\hline
\end{tabular}




\begin{tabular}{|c|c|}
\hline CPMAI & $\begin{array}{l}\text { The Cognitive Project Management for AI is a methodology that is } \\
\text { optimized for the delivery of in-production, high value, low risk AI } \\
\text { projects. The CPMAI methodology also incorporates the latest } \\
\text { practices in Agile Methodologies. }\end{array}$ \\
\hline Dark Data & $\begin{array}{l}\text { Dark data is data which is acquired through various computer network } \\
\text { operations but not used in any manner to derive insights or for } \\
\text { decision making. The ability of an organization to collect data can } \\
\text { exceed the throughput at which it can analyze the data. In some cases, } \\
\text { the organization may not even be aware that the data is being } \\
\text { collected. }\end{array}$ \\
\hline Data Science & $\begin{array}{l}\text { Data science is an interdisciplinary field that uses scientific methods, } \\
\text { processes, algorithms and systems to extract knowledge and insights } \\
\text { from many structural and unstructured data. }\end{array}$ \\
\hline Descriptive Analytics & $\begin{array}{l}\text { Descriptive analytics is a preliminary stage of data processing that } \\
\text { creates a summary of historical data to yield useful information and } \\
\text { possibly prepare the data for further analysis. }\end{array}$ \\
\hline Goal-driven Systems & $\begin{array}{l}\text { In this particular pattern, the challenge that machines address is the } \\
\text { need to find the optimal solution to a problem. Regardless of the } \\
\text { specific need, the power that we're looking for here is the idea of } \\
\text { learning through trial-and-error, and determining the best way to } \\
\text { solve something, even if it's not the most obvious. }\end{array}$ \\
\hline Hyper Personnalisation & $\begin{array}{l}\text { The hyper personnalisation pattern is defined as using machine } \\
\text { learning to develop a profile of each individual, and then having that } \\
\text { profile learn and adapt over time for a wide variety of purposes } \\
\text { including displaying relevant content, recommending relevant } \\
\text { products, providing personalized recommendations and so on. The } \\
\text { objective of this pattern is to treat each individual as an individual. }\end{array}$ \\
\hline IoT & $\begin{array}{l}\text { The Internet of things (IoT) is a system of interrelated computing } \\
\text { devices, mechanical and digital machines provided with unique } \\
\text { identifiers (UIDs) and the ability to transfer data over a network } \\
\text { without requiring human-to-human or human-to-computer interaction. }\end{array}$ \\
\hline Patterns \& Anomalies & $\begin{array}{l}\text { The goal of the Patterns and Anomalies pattern of AI is to use } \\
\text { machine learning and other cognitive approaches to learn patterns in } \\
\text { the data and learn higher order connections between data points to see } \\
\text { if it fits an existing pattern or if it is an outlier or anomaly. The object } \\
\text { of this pattern is to find what fits with existing data and what doesn't. }\end{array}$ \\
\hline PMO & $\begin{array}{l}\text { A project management office is a group or department within a } \\
\text { business, government agency, or enterprise that defines and maintains } \\
\text { standards for project management within the organization. The PMO } \\
\text { strives to standardize and introduce economies of repetition in the } \\
\text { execution of projects. }\end{array}$ \\
\hline $\begin{array}{l}\text { Predictive Analysis \& } \\
\text { Decision Support }\end{array}$ & $\begin{array}{l}\text { This is defined as using machine learning and other cognitive } \\
\text { approaches to understand how past or existing behaviors can help }\end{array}$ \\
\hline
\end{tabular}




\begin{tabular}{|l|l|}
\hline & $\begin{array}{l}\text { predict future outcomes or help humans make decisions about future } \\
\text { outcomes based on these patterns. The objective of this pattern is } \\
\text { helping humans make better decisions. }\end{array}$ \\
\hline Predictive Analytics & $\begin{array}{l}\text { Predictive analytics encompasses a variety of statistical techniques } \\
\text { from data mining, predictive modeling, and machine learning, that } \\
\text { analyze current and historical facts to make predictions about future } \\
\text { or otherwise unknown events. }\end{array}$ \\
\hline Prescriptive Analytics & $\begin{array}{l}\text { Prescriptive analytics makes use of machine learning to help } \\
\text { businesses decide a course of action based on a computer program's } \\
\text { predictions. Prescriptive analytics works with predictive analytics, } \\
\text { which uses data to determine near-term outcomes. }\end{array}$ \\
\hline Recognition Systems & $\begin{array}{l}\text { The recognition pattern is defined as using machine learning and } \\
\text { other cognitive approaches to identify and determine objects or other } \\
\text { desired things to be identified within image, video, audio, text, or } \\
\text { other primarily unstructured data formarily. The objective of this } \\
\text { pattern is to have machines identify and understand things. }\end{array}$ \\
\hline RPA & $\begin{array}{l}\text { Robotic process automation is a form of business process automation } \\
\text { technology based on metaphorical software robots or on artificial } \\
\text { intelligence /digital workers. }\end{array}$ \\
\hline SVM & $\begin{array}{l}\text { Support Vector Machine, This is a new way of learning, which is } \\
\text { more powerful than } \\
\text { traditional learning tools. It is able to solve data categorization } \\
\text { problems and regression problems as well. }\end{array}$ \\
\hline
\end{tabular}




\section{REFERENCES}

\section{Non-Internet References:}

24. H. K. Dam, T. Tran, J. Grundy, A. Ghose, Y. Kamei, "Towards effective AI-powered agile project management" 2018.

25. S. Elrajoubi "Artificial Intelligence in Project Management" 2019.

26. Martinez, D. M. and Fernandez-Rodriguez, J. C. (2015), Artificial Intelligence applied to project success: a literature review. Universidad Antonio de Nebrija, Madrid, Spain. International Journal of Artificial Intelligence and Interactive Multimedia, Vol. 3, No5.

39. Project Management Institute, 2017. A guide to the project management body of knowledge (PMBOK guide). Newtown Square, PA: Project Management Institute.

43. Desouza, K. C., \& Evaristo, J. R. (2006), Project management offices: A case of knowledge-based archetypes. International Journal of Project Management, 26(5), 414-423.

44. Gartner (2017), Digitalization's Impact on PPM Practices and the PMO by 2030. Gartner, Inc. | G00325444.

\section{Internet References (hyperlinks active as on 25th June, 2020) :}

1. Fast company, Adopt these 4 practices to successfully integrate AI into your organisations (2020), The future of work.

https://www.fastcompany.com/90504689/adopt-these-4-practices-to-successfullyintegrate-ai-into-your-organization

2. Atlassian, 3 ways AI will change project management for the better (2017) https://www.atlassian.com/blog/software-teams/3-ways-ai-will-change-projectmanagement-better

3. Forbes, Change Is Constant: This Is The New Work Ecosystem (2020), Business reported.

https://www.forbes.com/sites/businessreporter/2020/06/08/change-is-constant-this-isthe-new-work-ecosystem/\#5d3c38d760d9

4. Forbes, Ron Schmelzer, AI In Project Management (2019), Cognitive World https://www.forbes.com/sites/cognitiveworld/2019/07/30/ai-in-projectmanagement/\#3685ae6ab4a0

5. Macy Bayern, How project managers are essential to to AI deployment (2019) https://www.techrepublic.com/article/how-project-managers-are-essential-to-aideployment/

6. Olivia Montgomery, 5 Benefits of Artificial Intelligence in Project Management (2020)

https://www.softwareadvice.com/resources/artificial-intelligence-projectmanagement-benefits/

7. Audrius Zujus, AI Project Development - How Project Managers Should Prepare (2018)

https://www.toptal.com/project-managers/technical/ai-in-project-management

8. Alison DeNisco Rayome, 6 AI technologies changing project management (2019) https://www.techrepublic.com/article/6-ai-technologies-changing-projectmanagement/

9. https://www.forbes.com/sites/cognitiveworld/2019/07/30/ai-in-projectmanagement/\#47aa9ce8b4a0

10. https://www.pwc.com/m1/en/publications/documents/virtual-partnership-artificialntelligence-disrupt-project-management-change-role-project-managers-final.pdf 
11. Cheyenne Noelle, Why AI is the Future of Finance (2019)

https://www.processmaker.com/resources/customer-success/blog/why-ai-is-thefuture-of-finance/

12. https://image-src.bcg.com/Images/BCG-CDRF-The-Impact-of-AI-on-the-FinancialJob-Market_Mar\%202018_ENG_tcm9-187843.pdf

13. https://security.toolbox.com/tech-101/10-industries-ai-will-disrupt-the-most-by-2030

14. https://emerj.com/ai-sector-overviews/ai-in-transportation-current-and-futurebusiness-use-applications/

15. https://www2.deloitte.com/us/en/insights/industry/financial-services/artificialintelligence-ai-financial-services-frontrunners.html

16. https://www.pwc.ch/en/insights/risk/transformation-assurance-ai-will-transformproject-management-are-you-ready.html

17. https://www.pwc.ch/en/publications/2019/ai-will-transform-project-managementen2019-web.pdf

18. https://eithealth.eu/wp-content/uploads/2020/03/EIT-Health-andMcKinsey_Transforming-Healthcare-with-AI.pdf

19. https://www.forbes.com/sites/cognitiveworld/2019/07/26/how-ai-can-transform-thetransportation-industry/\#6e7ec0124964

20. https://pomodoneapp.com/blog.html/2019/08/31/impact-of-artificial-intelligence-inproject-

management/\#: :text=AI\%20can\%20even\%20automate\%20simple,and\%20improve ments\%20to\%20the\%20project.

21. https://www.clearpointstrategy.com/project-management-in-healthcare/

22. https://www.liquidplanner.com/blog/why-autonomy-matters-for-your-project-team/

27. https://www.cognilytica.com/cpmai-methodology/

28. https://www.scmp.com/business/china-business/article/2131903/biggest-limitationartificial-intelligence-its-only-smart

29. https://www.ibm.com/watson/advantage-reports/future-of-artificial-intelligence/aicreativity.html

30. https://www.nibusinessinfo.co.uk/content/risks-and-limitations-artificial-intelligencebusiness

31. PMI(2018), Pulse of Profession- Learning thought Leadership https://www.pmi.org/-/media/pmi/documents/public/pdf/learning/thoughtleadership/pulse/pulse-of-the-profession-2018.pdf

32. PwC(2018), Workforce of the Future :The competing forces shaping 2030 https://www.pwc.com/gx/en/services/people-organisation/workforce-of-thefuture/workforce-of-the-future-the-competing-forces-shaping-2030-pwc.pdf

33. PWC (2019), A Virtual Partnership: How AI will disrupt Project Management and change the role of Project Managers

https://www.pwc.com/m1/en/publications/documents/virtual-partnership-artificialntelligence-disrupt-project-management-change-role-project-managers-final.pdf

34. https://www.pmcolumn.com/tools-for-project-managers-to-travel-in-time/

35. https://www.forbes.com/sites/hecparis/2020/06/17/ai-risks-and-covid-19-five-lessonsmanagers-need-to-address/\#36d2a3cf2ca1

36. IBM Predictive Analytics https://www.ibm.com/analytics/predictive-analytics

37. https://www.forbes.com/sites/cognitiveworld/2019/07/30/ai-in-projectmanagement/\#53bd9556b4a0

38. https://cmte.ieee.org/futuredirections/2018/05/18/the-future-of-health-care-is-tied-tobig-data/

40. PWC (2019), A Virtual Partnership: How AI will disrupt Project Management and change the role of Project Managers 
https://www.pwc.com/m1/en/publications/documents/virtual-partnership-artificialntelligence-disrupt-project-management-change-role-project-managers-final.pdf

41. PWC (2018), AI will transform project management. Are you ready? https://www.pwc.ch/en/publications/2019/ai-will-transform-project-managementen2019-web.pdf

42. Quay Consulting (2018), Artificial Intelligence in the PMO: Does AI have a Place in Project Delivery?

https://www.quayconsulting.com.au/news/artificial-intelligence-in-the-pmo-does-aihave-a-place-in-project-delivery/

45. https://en.wikipedia.org/wiki/History_of_artificial_intelligence

46. How can we prevent project management from falling into the AI darkness? https://www.pwc.ch/en/publications/2019/How-can-we-prevent-AIDarkness_web.pdf

47. https://www.crunchbase.com/organization/cognilytica\#section-overview

48. Walch, K. (2019), The Seven Patterns Of AI.

https://www.forbes.com/sites/cognitiveworld/2019/09/17/the-seven-patterns-ofai/\#4988d87812d0

49. CB INSIGHTS (2020), AI 100: The Artificial Intelligence Startups Redefining Industries.

https://www.cbinsights.com/research/artificial-intelligence-top-startups/

50. Crunchbase Business Information (2020) : Aurora, company description https://www.crunchbase.com/organization/aurora-6292

51. LinkedIn, Butterfly Network, Inc. account https://www.linkedin.com/company/butterflynetwork

52. Crunchbase Business Information (2020) : Recursion Pharmaceuticals, company description

https://www.crunchbase.com/organization/recursion-pharmaceuticals

53. C3.ai, company website (2020)

https://c3.ai/company/

54. Crunchbase Business Information (2020) : Tesla Motors, company description https://www.crunchbase.com/organization/tesla-motors\#section-overview

55. Markowski, K (2008), Actor-Network-Theory for Project Management: use it or bin it?

https://www.researchgate.net/publication/275655047_Actor-Network-

Theory for_Project_Management_use it_or_bin_it_2008 at_22nd_IPMA_Rome_W orld_Congress___Project_Management_to_Run

56. Markowski, K., Csösz, S. (2008), Emerging controversies in project management and their impact on the dynamics between project practitioners, consultants and researchers.

https://www.researchgate.net/publication/237676135_Emerging_controversies_in_pro ject_management_and_their_impact_on_the_dynamics_between_project_practitioner s_consultants_and_researchers 